This PDF is a selection from an out-of-print volume from the National Bureau of Economic Research

Volume Title: An Appraisal of the 1950 Census Income Data

Volume Author/Editor: Conference on Research in Income and Wealth

Volume Publisher: Princeton University Press

Volume ISBN: 0-691-04102-4

Volume URL: http://www.nber.org/books/unkn58-2

Publication Date: 1958

Chapter Title: Some Income Adjustment Results from the 1949 Audit Control Program

Chapter Author: Marius Farioletti

Chapter URL: http://www.nber.org/chapters/c1055

Chapter pages in book: (p. 241 - 286) 


\title{
Some Income Adjustment Results from the 1949 Audit Control Program
}

\author{
Marius Farioletti, PlanNing Division,
}

INTERNAL REVENUE SERVICE

\section{Purpose of the Audit Control Programs}

In the broadest sense, the Audit Control Programs were an ambitious and complicated venture into the field of quantitative analysis in the attempt to speed up the audit improvements needed to cope with the vastly greater responsibilities placed on the Internal Revenue Service during World War II and since. The programs used the technique of probability sampling to select representative tax returns for audit. The results were tabulated to produce statistics representing the size and nature of the audit problems of federal taxpayers and administrators.

However, the programs were not merely a fact-collecting project. Through the development of new tax return processing and selection procedures, the objectivity and sharpness inherent in quantitative analysis were, to some extent, combined with the practical knowledge of the experienced audit manager. The programs also made clear the need to develop similar basic information about the regular audit programs. This information is now being gathered, and it shows how far audit problems are actually being covered by the regular examination procedures. Any areas that are being too thinly or heavily covered are brought to light. In this way, by balancing the case experience of examining officers with the facts about the size and relative importance of different audit problems, more effective tax enforcement is being attained.

The stated objectives of the ACP involving the 1948-1950 income years for individual income tax returns, and the 1949 income year for corporations with assets under $\$ 250,000$ were primarily:

1. To provide a sound basis for estimating the total audit workload for the types of tax returns covered by the programs.

Note: While the writer is responsible for the preparation of this paper, the materials are largely the products of group research and thinking of staff members of the Internal Revenue Service's Planning and Statistics Divisions. Particular credit should be given to C. W. Anderson, T. E. McHold, A. C. Rosander, W. C. Shoup, and J. H. Wilson, Statistics Division; C. B. Fine, Appellate Division; and J. W. Connaughton, Planning Division. Mr. Rosander and Mr. Fine are responsible for the preparation of the appendix materials on sampling and estimating methods. 


\section{MATCHING AND QUALITY STUDIES}

2. To improve the existing procedures for selecting for regular examination or audit erroneous tax returns with relatively large tax errors.

3. To find out which types of tax errors should be attacked by new laws, new regulations, and, if possible, new ways of explaining tax ideas to mistaken taxpayers, many of whom are willing to comply with the tax laws if they can only be taught how.

4. In addition to exploring the size and nature of the audit problems of the individual and corporate income taxes, the 1949 program was expected to provide information on the feasibility of auditing all federal tax returns of one taxpayer during one examination, including withholding and pay roll taxes and certain excises.

The tax administrator is not primarily in the business of producing statistics. Consequently, when he undertakes a big project such as the ACP he expects practical results rather quickly. Thus none of the stated objectives include the production of income information helpful in evaluating the income estimates made by federal and other agencies.

The 1949 program was designed to permit the tabulation of income adjustments, since this information was considered to be a desirable by-product. However, no additional funds were made available for this purpose. Therefore the estimates of income adjustments to be found if all tax returns of the described types were examined are by-products of tabulations made for the express purpose of attaining the stated objectives. Owing to the limited resources which could be made available for the ACP tabulations and the analyses of the 1949 ACP results, only a limited amount of the income adjustment information collected has been tabulated and no further tabulations are planned.

\section{Methods Used in the Programs}

\section{SELECTING THE SAMPLE RETURNS FOR AUDIT}

Even before the results of the 1948 program were received and tabulated, let alone analyzed, it was necessary to start the program for the 1949 returns. The 1949 program included another, but smaller, sample of individual returns, a sample of small corporation returns-largely those with assets under $\$ 250,000$, and an examination of the pay roll and certain excise tax returns of these same groups. The Statistics of Income estimates, which have been produced by the IRS Statistics Division for many years from income tax returns filed, not only indicated the characteristics that the ACP 


\section{AUDIT CONTROL PROGRAM}

sample should take but also provided a fund of reliable information without which the audit problem could not have been as clearly defined.

In brief, the audit control sample for 1949 individual income tax returns was a subsample of the Statistics of Income sample of about 620,000 returns. This subsample involved about 65,000 individual income tax returns stratified by type of return (Forms 1040A versus Forms 1040), size of adjusted gross income, and type of income. Each timely filed individual income tax return had a predetermined probability of inclusion in the sample. A higher sampling rate was used to select returns reporting business incomes than to select returns reporting only nonbusiness incomes. (Detailed explanations of the individual income tax sample and of the estimating methods used are contained in the Appendix.)

In contrast, the 1949 sample of corporation income tax returns filed covers only those returns with assets under $\$ 250,000$ and those filed without balance sheets, accounting for about 80 per cent of all of the 1949 corporation income tax returns filed. The sample consisted of about 16,000 returns of these small corporations, or about 3 per cent of the total number of returns filed in the four asset classes included in the program. However, the sample was stratified by asset classes and by broad industry classes, and was sampled accordingly.

The corporation audit sample was limited to the mass of small corporations because they seemed to be about the only type of corporate taxpayer that could be thoroughly examined and the results tabulated and analyzed within the time limits of the ACP. The examinations of the larger corporations are frequently so complicated and technical that several years' time is required to complete the investigations, discussions, and conferences needed to reach the final stages of agreement or disagreement within the administrative procedures of the IRS. (The technical details of the sampling and estimating procedures for the corporation income tax returns are also contained in the Appendix.)

To complete the record, the audit sample for 1949 excise and pay roll tax returns was a derivative sample. It was a probability subsample automatically derived from the samples of both individual and corporation returns. Taxpayers with business incomes, whose 1949 income tax returns were selected under the sampling procedures indicated above, were automatically selected for excise and pay roll tax audits if they were required to file returns for withholding, federal insurance contributions, federal unemployment, some of the admissions taxes, and the four retail excise 
taxes. This derivative sample was believed to be the most appropriate one for analyzing the complex of business-taxpayer problems at the federal level.

\section{CONTROLLING THE QUALITY OF THE RESULTS}

From the beginning, it was believed that the largest potential sources of error lay in the field offices of the Service as compared with sampling and processing errors. As the result of close collaboration among personnel of the Service's then Management Staff, Statistical Division, Accounts and Collections Unit, and Income Tax Unit in Washington, and of regional conferences with the field office staffs, instructions covering the operations of the program were developed. In addition, as new questions were raised during the course of operations, supplements to these instructions were issued on questions of general interest, and individual letters prepared on purely local questions.

At the planning stage of the project it had been concluded that it would not be practicable to establish standards of audit needed to estimate all errors that taxpayers make. Consequently, it was proposed to estimate the errors that experienced Internal Revenue investigators would find if all returns were thoroughly audited.

To implement this decision and to assure geographical uniformity of the results, the following standards of performance were established for the ACP:

1. The examining officers assigned sample returns for examination had to be experienced and capable of performing fully the job intended.

2. The audit had to be conducted by personal interview with the taxpayer or his representative and had to cover the examination of books and records, if any. Correspondence audits, therefore, were not permissible.

3. The sample return had to be intensively investigated to make certain that all taxable income had been reported, that all nontaxable income had been excluded; all deductions, credits, and exemptions claimed were properly allowable; and that all deductions, credits, and exemptions properly allowable had been claimed.

4. When the sample return selected was the separate return of a spouse, the related return of the other spouse also had to be examined. Similarly, when the audit sample return included income from a partnership or fiduciary, these related returns had to be examined to establish the accuracy of the income reported on the sample return. 


\section{AUDIT CONTROL PROGRAM}

After the samples of $\mathrm{ACP}$ returns were drawn in Washington, they were properly identified and returned to the originating collectors' and agents' offices for examination. ${ }^{1}$ After the examination the data desired were entered by the examining officers on special check sheets designed specifically for ACP purposes in accordance with the precise instructions issued. There the officers assigned to review the regular income tax reports of the office auditors, deputy collectors, and Internal Revenue agents were also assigned the responsibility of reviewing the adequacy and accuracy of audit information provided in the check sheets. After the examinations had been concluded and the results accepted by both the field offices and the taxpayers, the 1949 sample returns with the examination file were shipped to Washington for "post-review." There, the responsibility for editing the sample check sheets was placed with the Income Tax Division where the editing work was carried on jointly with the post-review of regular audit reports. Not until after this final post-review were the 1949 check sheets made available to the Statistics Division for statistical processing.

The ACP estimates do not represent all of the errors that taxpayers make, but only the errors that experienced Internal Revenue examining officers would find if all of the returns of the taxpayers were audited with about the same experience and time factors. If more time and more experienced personnel were to be applied to the examination of the same sample of returns, additional errors would probably be found. The reverse is also true, if less experienced examining officers or less time had been spent on the 1949 ACP returns, fewer and smaller errors, on the average, would have been disclosed.

No one really knows the size of the difference between errors disclosed and errors made. Some of the undisclosed errors resulted from oversight, others involved highly technical interpretations of factual and legal situations, and others involved fraud. No one knows the relative proportions of the undisclosed errors by source. It will never be possible to find all of the errors that taxpayers make, since some will be more or less successful in concealing information necessary to the correct determination of tax liability. Consequently, the ACP results are subject to errors one cannot segregate or estimate to establish the total income actually received by the individuals and persons covered by the program.

\footnotetext{
${ }^{1}$ At that time the Internal Revenue Service divided its individual income tax enforcement work into two parts: (1) the great mass of lower income tax returns with adjusted gross incomes under $\$ 7,000$ were under the audit jurisdiction of the sixty-four collectors of Internal Revenue; and (2) the much smaller number of individual income tax returns with adjusted gross incomes over $\$ 7,000$ and all corporation income tax returns were under the audit jurisdiction of the thirty-nine Internal Revenue agents in charge of the field offices of the Income Tax Division.
} 


\section{Estimates of Income Changes}

As previously indicated, all of the materials relating to income changes obtained by the 1949 ACP have not been tabulated. The income estimates made have been by-products of tabulations of other tax adjustment data designed to help answer questions pertaining to enforcement programs. Consequently, the estimates presented below do not comprise an integrated whole or neat pattern, and are, in a sense, fragments. We hope, however, that they will help students of income and wealth to evaluate the adequacy of the existing data on income and its distribution.

\section{WAGE AND SALARY CHANGES ON FORMS 1040A}

Table 1 presents estimates of changes found in the amounts of salaries and wages subject to withholding tax that were reported on the 1949 Form 1040A returns filed. ${ }^{2}$ These estimates are distributed between returns with changes only in the withheld class of wages and salaries and returns in which other income changes were also made.

About 16.8 million Forms $1040 \mathrm{~A}$ were filed and, at the time the estimates were made, audit results had been received on sample returns representing 16.1 million or over 96 per cent of the returns filed. The estimates show that about 464,000 returns, or less than 3 per cent of the 16.1 million, would probably have a change in wages and salaries subject to the withholding tax after examination. ${ }^{3}$ The total estimated change is $\$ 110$ million, or 0.3 per cent of the $\$ 35.1$ billion of adjusted gross income estimated to have been reported on the covered returns. On the average, 1.7 hours of examination time (including official travel ${ }^{4}$ and report writing time) was spent per sample Form 1040A return audited.

About 347,000 or 75 per cent, of the 464,000 returns with change in salaries and wages subject to withholding showed change only in such salaries and wages. These returns accounted for $\$ 85$ million, or over 77 per cent of the $\$ 110$ million of the total change in salaries and wages subject to withholding. The other 25 per cent of returns with changes in salaries and wages subject to withholding also showed changes in other items on the Form 1040A return.

${ }^{2}$ A Form 1040A may be filed by a wage earner with adjusted gross' income under $\$ 5,000$, provided not more than $\$ 100$ of such income is from wages not subject to withholding and from dividends and interest.

8 "Change" means both increases and decreases in the adjusted items. In the case of wages and salaries, the decrease adjustments are relatively unimportant.

'Most Form 1040A returns were examined at Internal Revenue offices and very little travel time was involved. 
Thus, 22,000, or about 5 per cent, also showed a change in wages and salaries not subject to withholding. These returns accounted for $\$ 4$ million, or less than 4 per cent of the total change in salaries and wages subject to withholding. About 35,000 , or less than 8 per cent of the 464,000 change returns, also showed change in interest and dividends. This group of returns accounted for less than $\$ 4$ million of the change in salaries and wages subject to withholding. In about 41,000 , or 9 per cent of the change returns, exemption changes were found, and these returns accounted for about $\$ 15$ million, or 14 per cent of the total change in salaries and wages subject to withholding.

To explain the reason for this exclusive interest in wages subject to withholding, this tabulation was designed as part of a general project attempting to determine the relative importance among Form $1040 \mathrm{~A}$ returns filed of misreporting of wages subject to withholding and therefore subject to check by information documents. It also indicated the relative importance of attempts to follow up other potential errors on the Form 1040A tax return when the examination originated from a lead furnished by an unmatched or mismatched information document.

\section{INCOME CHANGES ON FORMS 1040 WITH INCOMES UNDER $\$ 10,000$}

Table 2 presents estimates of changes found in the amounts of adjusted gross income that were reported on the 1949 Form 1040 returns with adjusted gross incomes under $\$ 10,000$. These estimates are distributed between returns with no change in tax liability from that originally reported when filed, and returns with change in tax liability.

About 34.1 million Forms 1040 with incomes under $\$ 10,000$ were filed and, at the time the estimates were made, audit results had been received on sample returns representing 33.4 million or 98 per cent of the returns filed. These returns reported about $\$ 101$ billion of adjusted gross income, and it is estimated that examination of all of them would have disclosed a change of about $\$ 4$ billion in the reported income, or 4 per cent of the reported amount. The estimates show that about 11.2 million returns, or almost 34 per cent of the 33.4 million, would probably result in a change in tax liability of $\$ 2$ or more upon examination. The estimated change in adjusted gross income on this group of returns is $\$ 3.8$ billion, or almost 10 per cent of the $\$ 40.3$ billion of adjusted gross income estimated to have been reported. Only $\$ 359$ million of change in adjusted gross income is estimated for the no tax change returns. 


\section{MATCHING AND QUALITY STUDIES}

This was about 0.6 per cent of the $\$ 60.7$ billion of adjusted gross income reported on this group of returns when filed. On the average, 3.1 hours of examination time (including official travel and report writing time) was spent per sample audit of Form 1040 returns with adjusted gross incomes under $\$ 10,000$. The average was 2.4 hours of examination time on such returns without business income, and 6.3 hours on those with business income. ${ }^{5}$

Table 3 distributes the tax change returns by major source of tax error. ${ }^{8}$ It shows about 5.9 million or 52 per cent of the returns with tax error with the major source of error in adjusted gross income. These returns accounted for $\$ 3.7$ billion, or almost 90 per cent of the $\$ 4.1$ billion of total change in adjusted gross income from the more than 33 million Form 1040 returns estimated to have been available for examination. The other 48 per cent of returns with tax change accounted for 2 per cent of the total change in adjusted gross income.

Table 4 distributes the estimated income changes likely to be found on the 5.9 million returns with adjusted gross income as the major source of tax error by twelve kinds of major income error. ${ }^{7}$ It shows that the 2.2 million returns (or 20 per cent of the 11.2 million with tax change) with the major error in business income or loss accounted for about $\$ 2.3$ billion of adjusted gross income change, or 59 per cent of the adjusted gross income change on the 11.2 million tax change returns, and 54 per cent of the total adjusted gross income change on the 33.4 million returns that were available for examination. Of the remaining eleven classes of major income error, the three representing income from partnerships, sales or exchanges of capital assets, and rents and royalties each accounted for 6 per cent to 8 per cent of the total adjusted gross income change on the 33.4 million returns. Three more classes, both wages and salaries subject to withholding and those not subject, and the residual "other" class, each accounted for 3 per cent to 5 per cent of the total change in adjusted gross income. The adjusted gross income changes accounted for by the other five classes of major income error were all under 2 per cent of the total.

\section{CHANGES IN BUSINESS INCOMES}

Table 5 presents estimates of changes found in the amounts of gross receipts and net profit or loss reported from businesses and

${ }^{5}$ That is, income reportable on Schedule C or Form 1040F.

${ }^{B}$ That is, the largest portion of the tax change is attributable to the indicated source listed in Table 3.

${ }^{7}$ That is, the largest portion of the change in adjusted gross income is attributable to the kind of income specified in Table 4. 
professions on all 1949 Forms 1040 with Schedule C and Form 1040F. ${ }^{8}$ These estimates are listed by about sixty business groups, along with the sample count for each group.

At the time these estimates were made, audit results had been received on 35,872 sample returns representing about 6.7 million business returns filed. The estimates show that about $\$ 105.5$ billion of gross receipts was reported on the returns and that examination of all of them would probably have disclosed a total of $\$ 107.4$ billion in gross receipts, an increase of $\$ 1.9$ billion or less than 2 per cent of the gross receipts reported on the covered returns when filed. The percentage change in the aggregate gross receipts as reported and as disclosed by audit varies from a -0.2 per cent for returns reporting gross receipts from mining and quarrying to a high of 4.5 per cent from returns reporting gross receipts classifiable into the "other professional and social services" group. ${ }^{9}$

The aggregate net profit less net loss reported on the 6.7 million returns when filed was about $\$ 13.6$ billion. The estimates indicate that examination of all of the returns filed would increase this aggregate to $\$ 16.3$ billion, an increase of $\$ 2.7$ billion, or 20 per cent. The difference between the increase of $\$ 1.9$ billion of gross receipts and $\$ 2.7$ billion in aggregate net profit less net loss, or $\$ 0.8$ billion, is attributable to unallowable and disallowed business deductions. The present increase in aggregate net profits less net loss varies from a low of 2.9 per cent on the returns of accountants to a high of 39.4 per cent on returns listing receipts from the manufacture of lumber and wood products, except furniture. The aggregate net loss in mining and quarrying was decreased 64.4 per cent.

Table 6 also presents estimates of changes found in the amounts of gross receipts reported on all 1949 Forms 1040 with Schedule C and Form 1040F. These gross receipts estimates differ from those in Table 3 in that (1) the aggregate of increases and the aggregate of decreases are shown separately instead of being presented as a net amount, (2) the estimates are listed for 17 instead of 60 business groups, and (3) the sample counts are different.

At the time the Table 6 estimates were made, audit results had been received on 36,176 sample returns representing about 6.9 million business returns filed. The estimates still show that about $\$ 105.5$ billion of gross receipts was reported on the returns filed and that examination of all of them would probably have disclosed

\footnotetext{
${ }^{8}$ Partnership income was not covered by this definition of business income because the ACP studies were attempting to identify erroneous returns by, among other things, kinds of income reported on the return as filed.

"The percentage increase in gross receipts for the "not allocable or unknown" group was 4.8 per cent.
} 
a net increase of $\$ 1.9$ billion or 1.8 per cent of the gross receipts originally reported. The estimates indicate that about 1.5 million returns would have shown an increase after examination of $\$ 2.1$ billion in gross receipts, or an average of $\$ 1,414$ per return with an increase. About 225,000 returns would have shown a decrease in gross receipts aggregating about $\$ 220$ million, or an average decrease of $\$ 981$ per return. Thus, over 1.7 million returns with business income, or 25 per cent of the 1949 population, apparently would have shown a change in gross receipts upon examination. The gross change is estimated to be about $\$ 2.4$ billion, and the net change is estimated as an increase of about $\$ 1.9$ billion in gross receipts.

In Table 7 the estimates of total returns and gross receipts reported and the total changes therein disclosable by audit that were presented in Table 6 are now given by size of adjusted gross income reported on the return when filed. In Table $7, \$ 1.5$ billion, or 71 per cent of the $\$ 2.1$ billion increase in gross receipts, is accounted for by the 5.8 million returns (representing about 84 per cent of the population) reporting less than $\$ 7,000$ of adjusted gross incomes when filed. It shows that the changes in gross receipts disclosable by audit tend to decrease in relative importance as the size of adjusted gross income increases. Thus, in the class of returns with adjusted gross incomes under $\$ 7,000$, the gross change (i.e. the sum of increases and decreases) in gross receipts was 4.0 per cent (column 8 plus column 9) of the aggregate gross receipts reported. This percentage decreased to 1.2 per cent for the group of returns with adjusted gross incomes between $\$ 7,000$ and $\$ 25,000$; to 0.4 per cent for returns with adjusted gross incomes between $\$ 25,000$ and $\$ 100,000$; and, to 0.3 per cent in returns reporting adjusted gross incomes of $\$ 100,000$ and over. The relative importance of decreases in gross receipts, as a proportion of the gross change (i.e. column 9 divided by column 8 plus column 9), apparently increases as the size of adjusted gross income increases. Thus, on returns with incomes under $\$ 7,000$ the returns with decreases in gross receipts showed an aggregate decrease of $\$ 121$ million. This was 0.3 per cent of the aggregate gross receipts reported on all returns of this group, but it was over 7 per cent of the gross amount of adjustment aggregating $\$ 1,647$ million. On the group of returns reporting incomes of $\$ 100,000$ and over the aggregate decrease in gross receipts on returns showing such decreases was $\$ 0.8$ million, but 42 per cent of the gross change of $\$ 1.9$ million.

Table 8 distributes the estimates of returns, gross receipts, and changes therein by size of gross receipts reported on the returns 
when filed. It shows that $\$ 788$ million, or 37 per cent of the $\$ 2.1$ billion increase in gross receipts, is accounted for by the two classes of returns reporting either no gross receipts from business or under $\$ 7,000$ of such receipts. These two classes accounted for 59 per cent of the "available" returns. An additional $\$ 728$ million increase in gross receipts is accounted for by the class of returns reporting gross receipts of from $\$ 7,000$ to $\$ 25,000$. These three classes of returns accounted for 86 per cent of the returns in the population and 71 per cent of the increases in gross receipts disclosable by audit.

Table 8 also shows that the relative importance of the changes in gross receipts, when measured as a percentage of the gross receipts reported on the return as filed, decreases as the size of gross receipts reported increases. Thus, returns reporting gross receipts under $\$ 7,000$ averaged a gross change of 5.5 per cent of the gross receipts reported. Those reporting gross receipts of $\$ 100,000$ and over showed an average gross change of 0.5 per cent of the aggregate gross receipts reported. The relative importance of decreases in gross receipts disclosable by audit, as a percentage of the gross change, increases as the size of total receipts increases. Returns reporting total receipts under $\$ 7,000$ are estimated to have overreported their gross receipts by $\$ 34$ million, or about 5 per cent of the gross change of $\$ 630$ million. This percentage increases to 24 per cent for returns reporting total receipts of $\$ 100,000$ and over. In addition, Table 8 estimates that 439,000 returns that should have reported gross receipts from business did not do so. In about 272,000 of these returns the net profit or loss was apparently correctly reported, but in about 167,000 of them there was a change in gross receipts.

\section{CHANGES IN INCOME AND DEDUCTIONS ON CORPORATE RETURNS}

The Table 9 series presents estimates of changes that would be found on examination in the amounts of net income and net loss reported on all 1949 corporation returns filed with balance sheets showing net assets under $\$ 250,000$ or with incomplete or no balance sheets. Some of these estimates are also shown by the nine administrative regions of the IRS.

Table 9 merely gives the total estimated number of such corporate returns filed for the United States and by region, further distributed between those with current year net income and with net loss. It shows, for example, that an estimated 507,000 of these "small" corporate returns were filed, of which 295,000 reported current year net incomes and 212,000 reported current year net losses. 
Table 10 gives United States and regional estimates pertaining to the 295,000 returns reporting current year net incomes. The average examination time spent per sample return of this type was 13.2 hours. The table shows that, for the United States, about $\$ 2,272$ million of net income was reported on these returns, and that examination of all of them would probably have disclosed a net increase of $\$ 225$ million or almost 10 per cent of the net income originally reported. The estimates indicate that 141,000 returns would have shown an increase of $\$ 249$ million in net income upon examination, or an average of $\$ 1,767$ per return with an increase. About 17,000 returns showed a decrease in net income aggregating about $\$ 24$ million, or an average decrease of $\$ 1,393$ per return. Thus, over 158,000 returns with net income, or about 54 per cent of the population, apparently would show a change in net income upon examination. The gross change is estimated to be about $\$ 273$ million, and the net change is estimated as an increase of $\$ 225$ million in net income.

Table 11 gives United States and regional estimates regarding the 212,000 returns reporting current year net losses. The average examination time spent per sample return of this type was 11.0 hours. The United States estimates show that about $\$ 1,070$ million of net loss was reported on these returns, and that examination of all of them would probably have disclosed a net decrease of $\$ 174$ million or over 16 per cent of the net loss originally reported. The estimates indicate that about 11,000 returns would have shown an increase of $\$ 22$ million in net loss upon examination, or an average of $\$ 1,982$ per return with an increase. About 86,000 returns showed a decrease in net loss aggregating about $\$ 195$ million, or an average decrease of $\$ 2,284$ per return. Thus, over 96,000 returns with net loss, or almost 46 per cent of the population, apparently would have shown a change in net loss upon examination. The gross change is estimated to be about $\$ 217$ million, and the net change is estimated as a decrease of about $\$ 174$ million in net loss.

Tables 12 and 13 present estimates of changes in nine income items that would have been found during the examination of the 1949 net income and net loss corporation returns filed with balance sheets showing net assets under $\$ 250,000$ or with incomplete or no balance sheets.

Table 12 gives United States estimates pertaining to the 295,000 returns reporting current year net incomes, and shows that 34,900 income changes probably would have been found upon examination. ${ }^{10}$ About 26,500, or 76 per cent of the changes in income items,

\footnotetext{
${ }^{10}$ The total of item changes is not the equivalent of returns, since a return could have more than one item of change.
} 
involved $\$ 77$ million of increase in net income. About 8,400 items of income change relate to income decreases that would probably have been disclosed, aggregating about $\$ 31$ million. The estimates indicate that the 295,000 returns would have shown a net increase of $\$ 46$ million in net income from all changes in income items, and a gross change of $\$ 108$ million. About 15,000 returns showed a change in gross sales and receipts. This item accounted for about 42 per cent of all of income items changes, for 62 per cent of the $\$ 77$ million increase in net income, and for 65 per cent of the $\$ 31$ million decrease in net income. None of the other specific income items listed in Table 12 account for as much as 10 per cent of the income change. In the amount of increase column, "dividends" and "net long term capital gains" are the next largest change classes, and each account for a little less than 9 per cent of the gross increase of $\$ 77$ million. In the amount of decrease column, "royalties" with 7 per cent of the $\$ 31$ million gross decrease, and "net long term capital gains" with 9 per cent are the next largest change categories.

Table 13 gives United States estimates pertaining to the 212,000 corporate returns reporting current year net losses, and shows that 23,500 items of income change probably would have been found upon examination. About 19,300, or 82 per cent of the changes in income items, involved $\$ 67$ million increase in income resulting in that amount of decrease in net loss. About 4,300 of the items of income change relate to income decreases that would probably have been disclosed upon examination. These aggregated about $\$ 14$ million, resulting in increases in net loss reported. The estimates indicate that the 212,000 net loss returns would have shown a net decrease of about $\$ 53$ million in net loss from all changes in income items, and a gross change of $\$ 81$ million. About 13,000 returns showed a change in gross sales and receipts. This item accounted for about 55 per cent of all income items changed, for 75 per cent of the $\$ 67$ million decrease in net loss, and for 66 per cent of the $\$ 14$ million increase in net loss. None of the other specific income items listed in Table 13 account for as much as 10 per cent of the income change. In the amount of increase column, "rents" and "net long term capital gains" are the next largest change classes accounting for about 6 per cent and 7 per cent, respectively, of the $\$ 67$ million gross decrease in net loss. In the amount of decrease column, "net gain from sale or exchange of other property" with 8 per cent of the $\$ 14$ million gross decrease, and "net long term capital gains" with 9 per cent are the next largest change categories involving increases in net loss.

Tables 14 and 15 present estimates of changes in sixteen deduc- 


\section{A TCHING AND QUALITY STUDIES}

tion items that probably would have been found during the examination of the 1949 net income and net loss corporation returns filed with balance sheets showing net assets under $\$ 250,000$ or with incomplete or no balance sheets.

Table 14 gives United States estimates pertaining to the 295,000 returns reporting current year net incomes, and shows that over 295,000 changes in deduction items probably would be found upon examination. About 214,000 , or 72 per cent of the item changes, involved decreases in taxpayer claims amounting to $\$ 221$ million increase in net income. About 82,000 of the deduction item changes involved raising taxpayer claims, aggregating $\$ 42$ million of net income decreases that would probably have been disclosed. The estimates indicate that the 295,000 net income returns would have shown a net increase of about $\$ 179$ million in net income from all changes in deduction items, and a gross change of $\$ 263$ million. About 25,000 returns showed a change in cost of goods sold and operations. This item accounted for about 9 per cent of all of deduction items changed, for 35 per cent of the $\$ 42$ million increase in deduction allowances, and for 24 per cent of the $\$ 221$ million decrease in deduction allowances. In the amount of increase column, "taxes" and "depreciation" are the next largest change classes and each account for a little more than 15 per cent of the gross increase in deductions allowances. In the amount of decrease column, "depreciation" with almost 14 per cent of the gross decrease in deductions allowances and "compensation of officers" with about 13 per cent are the next largest change categories. None of the other specific deduction items listed in Table 14 account for as much as 10 per cent of the amounts of change.

Table 15 gives United States estimates pertaining to the 212,000 returns reporting current year net losses, and shows that over 179,000 deduction items probably would have been changed upon examination. About 139,000 , or 78 per cent of the changes in deduction items, involved about $\$ 163$ million decrease in deductions claimed, resulting in that amount of decrease in net loss. About 40,000 of the deduction changes relate to allowable increases that would probably have been disclosed. These aggregated about $\$ 42$ million, resulting in increases in net loss after examination. The estimates indicate that the 212,000 net loss returns would have shown a net decrease of about $\$ 121$ million in net loss from all changes in deduction items, and a gross change of \$204 million. About 21,000 returns showed a change in cost of goods sold and operations. This item accounted for about 12 per cent of all deductions items changed, for 27 per cent of the $\$ 163$ million decrease 
in net loss from disallowing deductions claimed, and for 39 per cent of the $\$ 42$ million increase in net loss from allowing more deductions than were claimed. In the amount of increase column, "depreciation" and "net loss from sale or exchange of other property" are the next largest change classes accounting for about 24 per cent and 10 per cent, respectively, of the $\$ 42$ million gross increase in net loss. In the amount of decrease column, "depreciation" and "compensation of officers" with a little less than 10 per cent of the $\$ 163$ million gross decrease in net loss are the next largest change categories. None of the other specific deduction items listed in Table 15 accounts for as much as 10 per cent of the amounts of change.

The following summary table shows that about $\$ 179$ million or 80 per cent of the estimated $\$ 225$ million net increase in net income that would have been found upon examination of the 295,000 net income returns is attributable to the estimated net decrease in deduction items. Only 20 per cent of the net income increase derives from disclosed net increases in income items. As shown in Tables 10,12 , and 14, the changes for net income corporations, in millions of dollars, were as follows:

$\begin{array}{lrcc}\text { Table } 10 \text { change in net income } & \begin{array}{c}\text { Gross } \\ \text { Increase }\end{array} & \begin{array}{c}\text { Gross } \\ \text { Decrease }\end{array} & \begin{array}{c}\text { Net } \\ \text { Increase }\end{array} \\ \text { Table } 12 \text { change in income items } & 249.2 & 24.1 & 225.1 \\ \text { Table 14 change in deduction items } & 77.0 & 31.3 & 45.7 \\ \text { Sum of Tables 12 and 14 } & 221.4 & 42.0 & 179.4 \\ \text { Sum } & 298.4 & 73.3 & 225.1\end{array}$

The summary table for net loss corporations shows a similar story. About $\$ 121$ million, or 70 per cent, of the estimated $\$ 174$ million net decrease in net loss that would have been found upon examination of the 212,000 net loss returns is attributable to the estimated net decrease in deduction items. About $\$ 53$ million, or 30 per cent, of the net loss decrease derives from increases in income items. As shown in Tables 11, 13, and 15, the changes for net loss corporations, in millions of dollars, were as follows:

$\begin{array}{lccc}\text { Table } 11 \text { change in net loss } & \begin{array}{c}\text { Gross } \\ \text { Increase }\end{array} & \begin{array}{c}\text { Gross } \\ \text { Decrease }\end{array} & \begin{array}{c}\text { Net } \\ \text { Decrease }\end{array} \\ \text { Table } 13 \text { change in income items } & 21.7 & 195.3 & 173.6 \\ \text { Table 15 change in deduction items } & 14.1 & 66.8 & 52.7 \\ \text { Sum of Tables 13 and 15 } & 41.9 & 162.7 & 120.9 \\ & 56.0 & 229.6 & 173.6\end{array}$


TABLE 1

Estimated Audit Change in Salaries and Wages Subject to Withholding Tax from Amount Reported by Individuals on 1949 Form 1040A Individual Income Tax Returns

(numbers in thousands, dollars in millions)

\begin{tabular}{|c|c|c|c|}
\hline DESCRIPTION & $\begin{array}{c}\text { Number } \\
\text { of } \\
\text { Returns }\end{array}$ & $\begin{array}{c}\text { Adjusted } \\
\text { Gross Income } \\
\text { Reported }^{\circledR}\end{array}$ & $\begin{array}{l}\text { Change in } \\
\text { Salaries and } \\
\text { Wages }\end{array}$ \\
\hline $\begin{array}{l}\text { Total filed } \\
\text { Not available for examination } \\
\text { Available for examination }\end{array}$ & $\begin{array}{c}16,752.0^{\circ} \\
624.9^{\circ} \\
16,127.2\end{array}$ & $\begin{array}{r}\$ 36,435.6 \\
1,359.2 \\
35.076 .4\end{array}$ & $\begin{array}{c}\text { n.a. } \\
\text { n.a. } \\
\$ 109.7\end{array}$ \\
\hline $\begin{array}{l}\text { With change in salaries and wages } \\
\text { subject to withholding } \\
\text { With change in these alone } \\
\text { With change in these and also in: } \\
\text { Salaries and wages not subject } \\
\text { to withholding } \\
\text { Interest and dividends } \\
\text { Exemptions } \\
\text { Other, including combinations }\end{array}$ & $\begin{array}{l}22.1 \\
34.7 \\
41.0 \\
18.9\end{array}$ & $\begin{array}{l}\text { n.a. } \\
\text { n.a. } \\
\text { n.a. } \\
\text { n.a. }\end{array}$ & $\begin{array}{r}4.0 \\
3.7 \\
15.3 \\
1.7\end{array}$ \\
\hline
\end{tabular}

n.a. = not available.

Figures may not add to totals because of rounding.

astimated.

' Subject to withholding.

c Taxpayer could not be located or outside continental United States, sample audits not completed, and final settlements not made in time for inclusion in tabulation.

Source: Audit Control Program for 1949 Individual Income Tax Returns, Internal Revenue Service.

\section{TABLE 2}

Estimated Audit Change in Adjusted Gross Income from Amount Reported by Individuals Reporting under $\$ 10,000$ of Such Income on 1949

Form 1040 Individual Income Tax Returns

(numbers in thousands, dollars in millions)

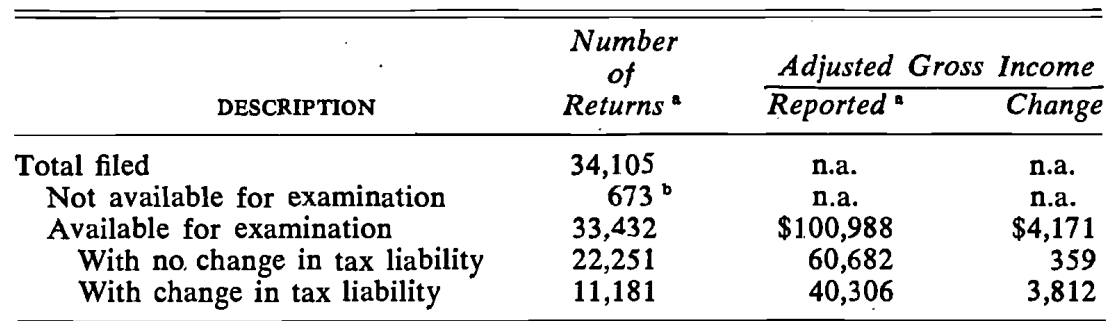

n.a. $=$ not available.

Figures may not add to totals because of rounding.

a Estimated.

- Taxpayer could not be located or outside continental United States, sample audits not completed, and final settlements not made in time for inclusion in tabulation.

Source: Audit Control Program for 1949 Individual Income Tax Returns, Internal Revenue Service. 


\section{TABLE 3}

Estimated Audit Change in Adjusted Gross Income from Amount Reported by Individuals Reporting under $\$ 10,000$ of Such Income on 1949 Form 1040 Individual Income Tax Returns and Whose Returns Indicated a Change in Tax Liability, by Major Source of Tax Error

(numbers in thousands, dollars in millions)

\begin{tabular}{|c|c|c|c|}
\hline \multirow[b]{2}{*}{ MAJOR SOURCE OF TAX ERROR } & \multirow{2}{*}{$\begin{array}{c}\text { Number } \\
\text { of } \\
\text { Returns }\end{array}$} & \multicolumn{2}{|c|}{ Adjusted Gross Income } \\
\hline & & Reported $^{\mathrm{b}}$ & Change ${ }^{b}$ \\
\hline Total ${ }^{\circ}$ & 11,181 & $\$ 40,306$ & $\$ 3,812$ \\
\hline Adjusted gross income & 5,857 & 20,334 & 3,730 \\
\hline Personal deductions & 3,225 & 12,910 & 14 \\
\hline Exemptions & 1,241 & 3,760 & 29 \\
\hline Arithmetic & 526 & 2,228 & 26 \\
\hline Tax table & 251 & 788 & 3 \\
\hline Not specified & 80 & 287 & 10 \\
\hline
\end{tabular}

Figures may not add to totals because of rounding.

${ }^{a}$ Major source of tax error means that the largest portion of tax change is attributable to the source listed. 'Estimated.

- Total returns with change in tax liability (last line of Table 2).

Source: Audit Control Program for 1949 Individual Income Tax Returns, Internal Revenue Service.

\section{TABLE 4}

Estimated Audit Change in Adjusted Gross Income from Amount Reported by Individuals Reporting under $\$ 10,000$ of Such Income on 1949 Form 1040 Individual Income Tax Returns Whose Returns Indicated a Change in Tax Liability with the Largest Portion Attributable to Error in Adjusted Gross Income, by Major Income Item in Error

(numbers in thousands, dollars in millions)

\begin{tabular}{|c|c|c|c|}
\hline \multirow[b]{2}{*}{ MAJOR INCOME ITEM IN ERROP " } & \multirow{2}{*}{$\begin{array}{c}\text { Number } \\
\text { of } \\
\text { Returns }\end{array}$} & \multicolumn{2}{|c|}{ Adjusted Gross Income } \\
\hline & & Reported $^{\mathrm{b}}$ & Change $^{b}$ \\
\hline Total ${ }^{\circ}$ & 5,857 & $\$ 20,334$ & $\$ 3,730$ \\
\hline Business income or loss & 2,207 & 7,048 & 2,261 \\
\hline Salaries and wages subject to withholding & 561 & 1,866 & 188 \\
\hline Deductions from salaries and wages & & & \\
\hline subject to withholding & 134 & 548 & 72 \\
\hline Salaries and wages not subject to & & & \\
\hline withholding & 422 & 1,116 & 119 \\
\hline Dividends & 220 & 871 & 49 \\
\hline Interest & 522 & 2,116 & 38 \\
\hline Rents and royalties & 822 & 3,110 & 264 \\
\hline Sale or exchange of capital assets & 391 & 1,614 & 286 \\
\hline Partnership & 360 & 1,258 & 329 \\
\hline Annuities and pensions & 25 & 81 & 5 \\
\hline Estates and trusts & 12 & 58 & 7 \\
\hline Other and not specified & 181 & 647 & 112 \\
\hline
\end{tabular}

Figures may not add to totals because of rounding.

- Major income item in error means that the largest portion of change in adjusted gross income is attributable to the income source listed. 'bstimated.

- Total returns with change in tax liability where the largest portion of tax change is attributable to error in adjusted gross income (second line of Table 3).

Source: Audit Control Program for 1949 Individual Income Tax Returns, Internal Revenue Service. 


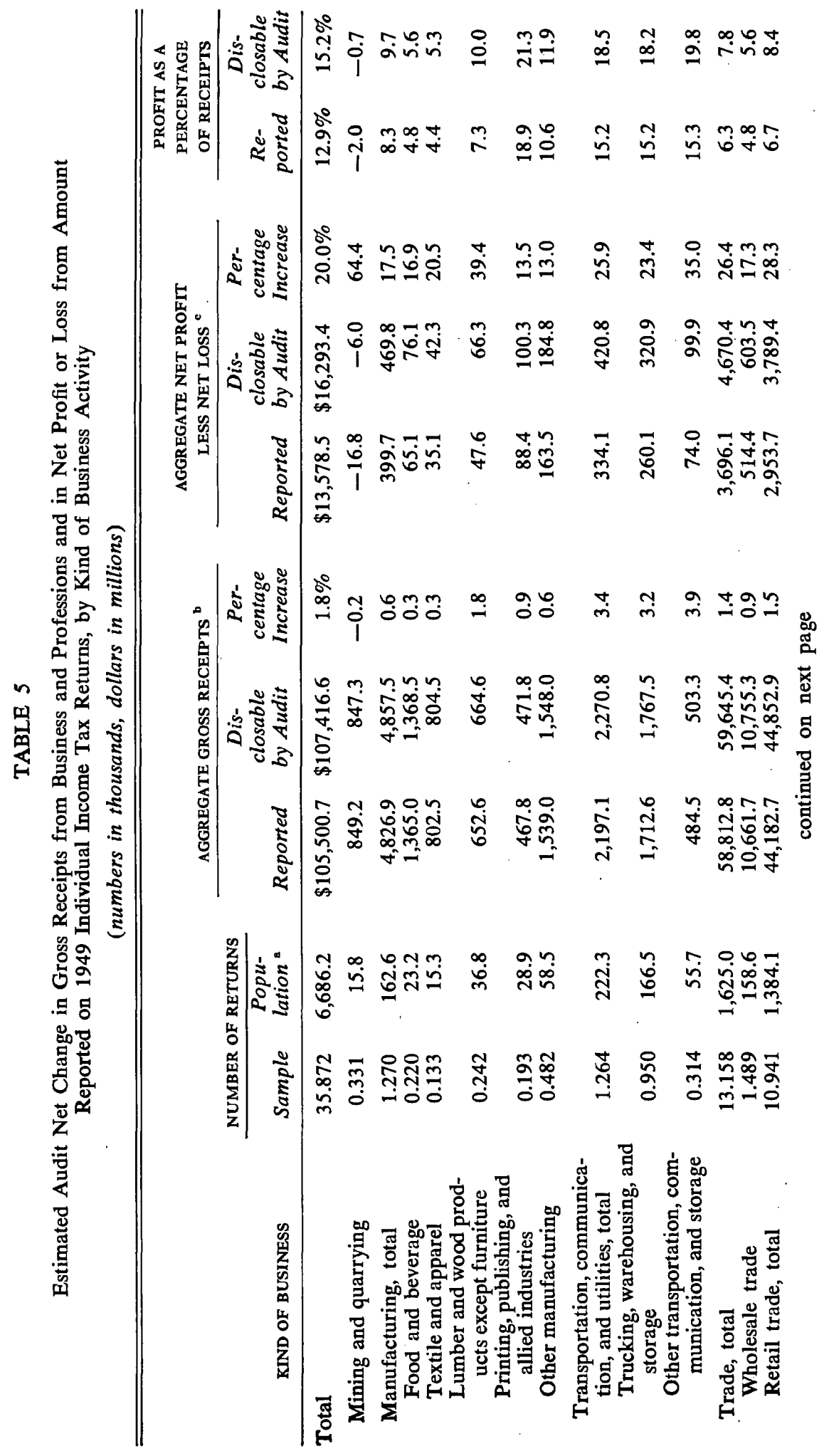




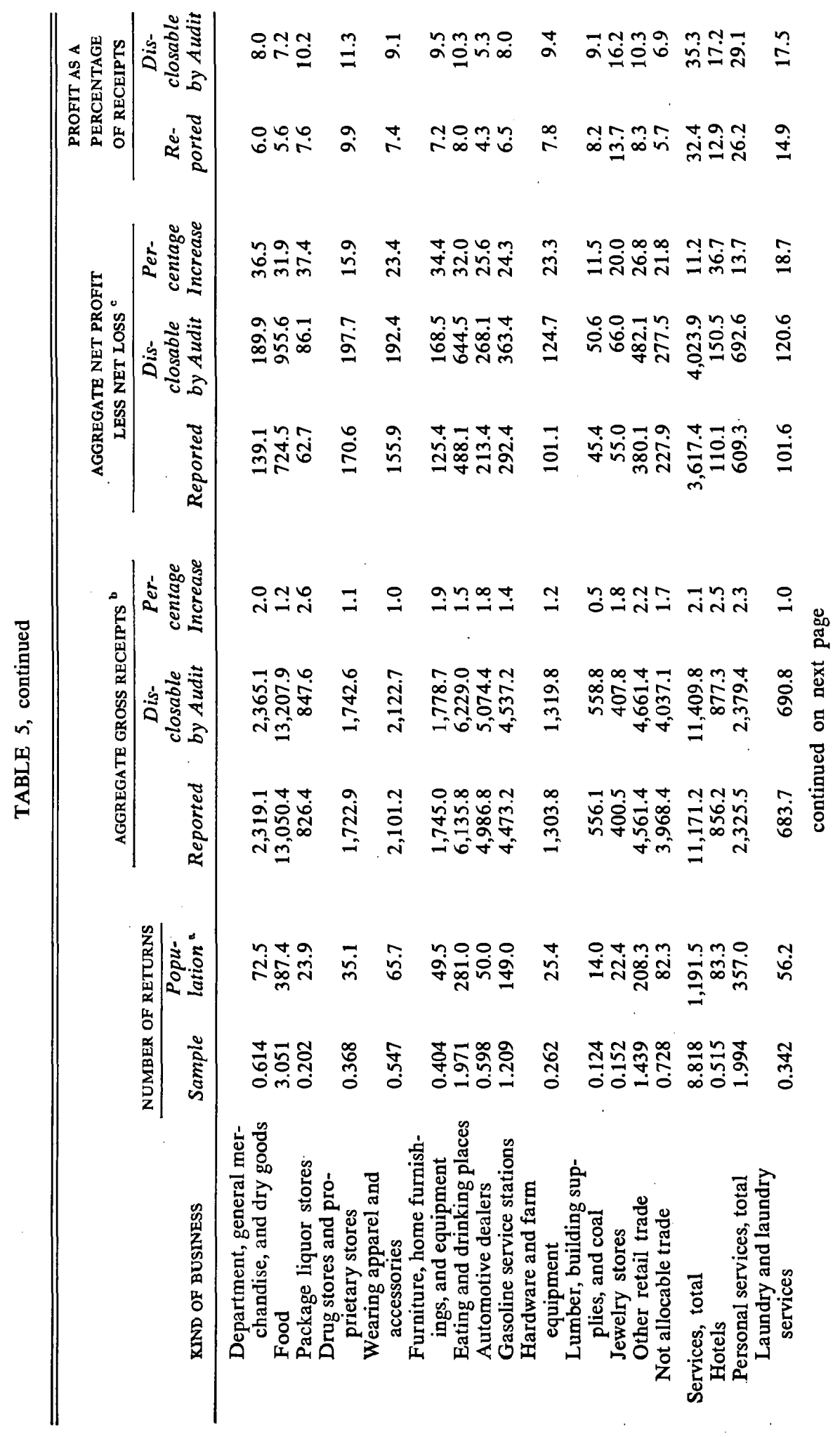




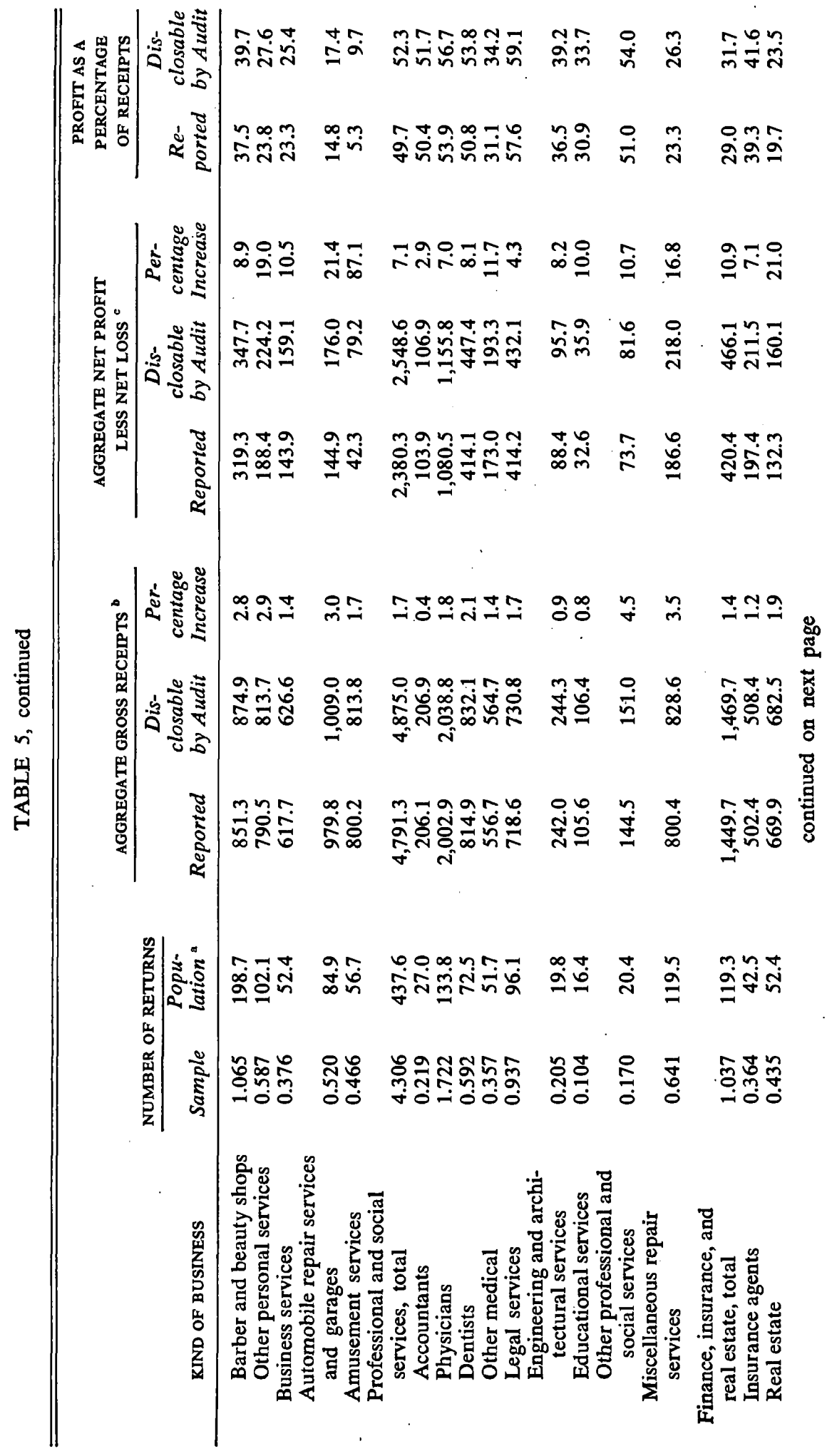




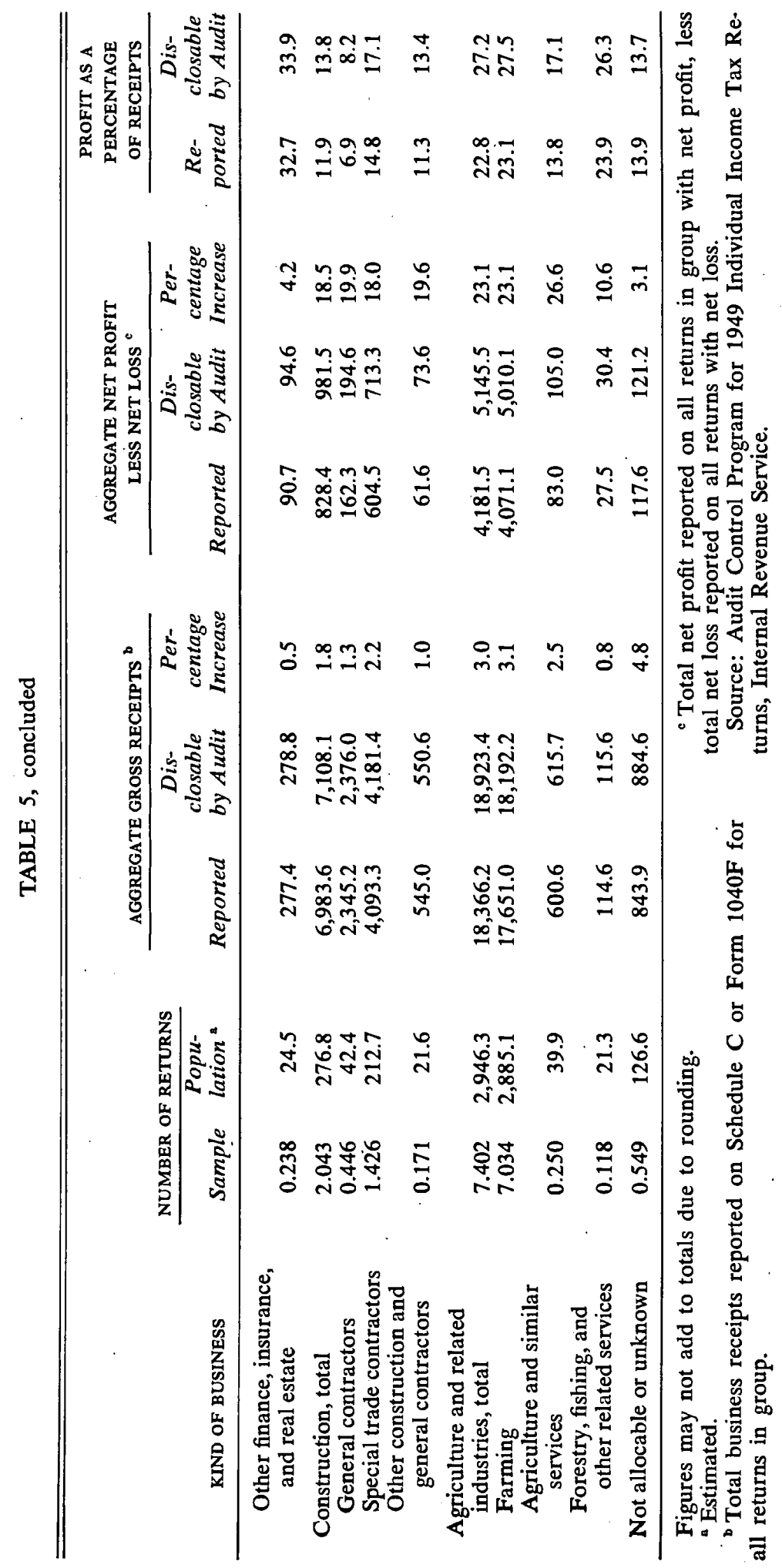




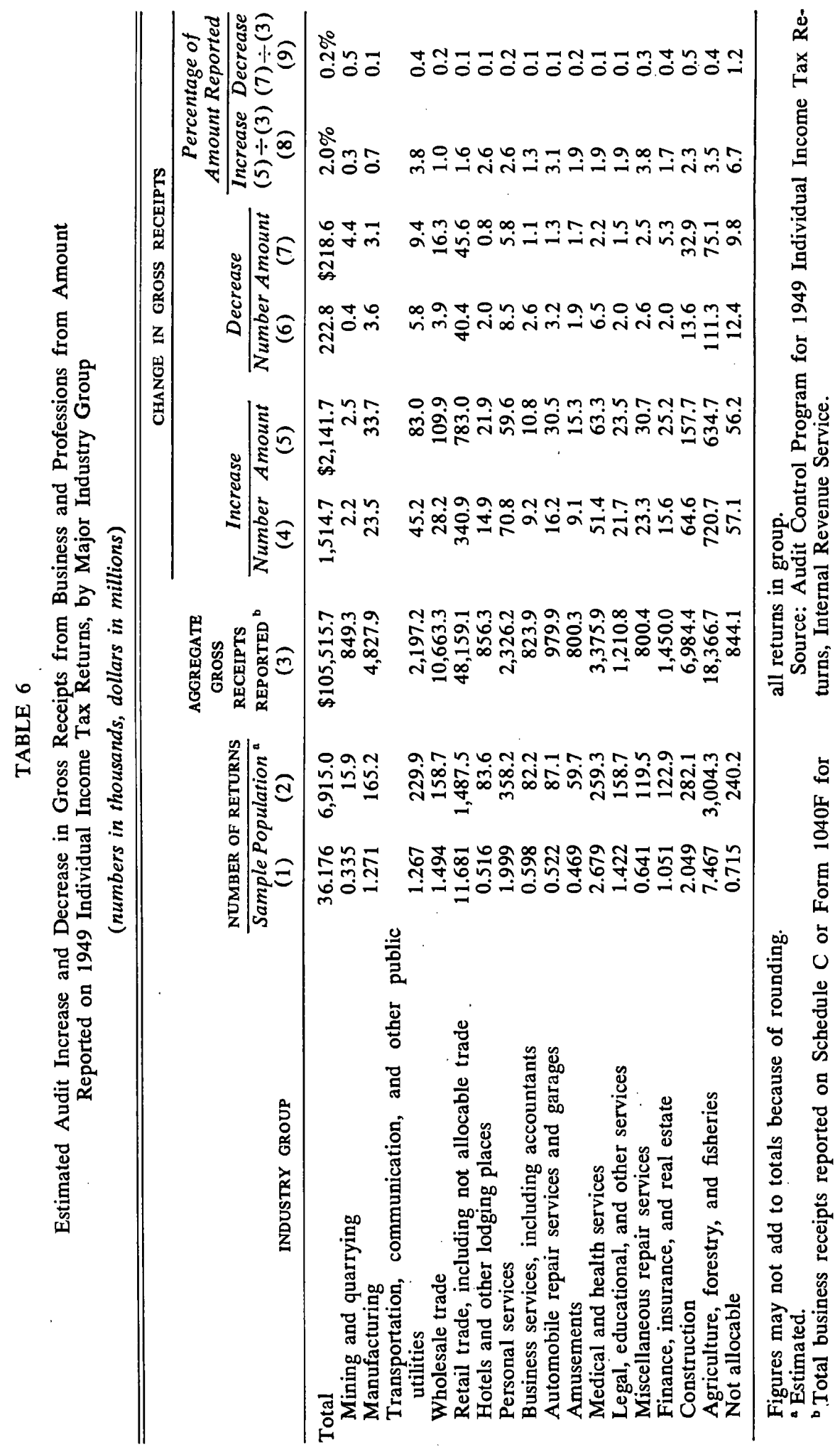




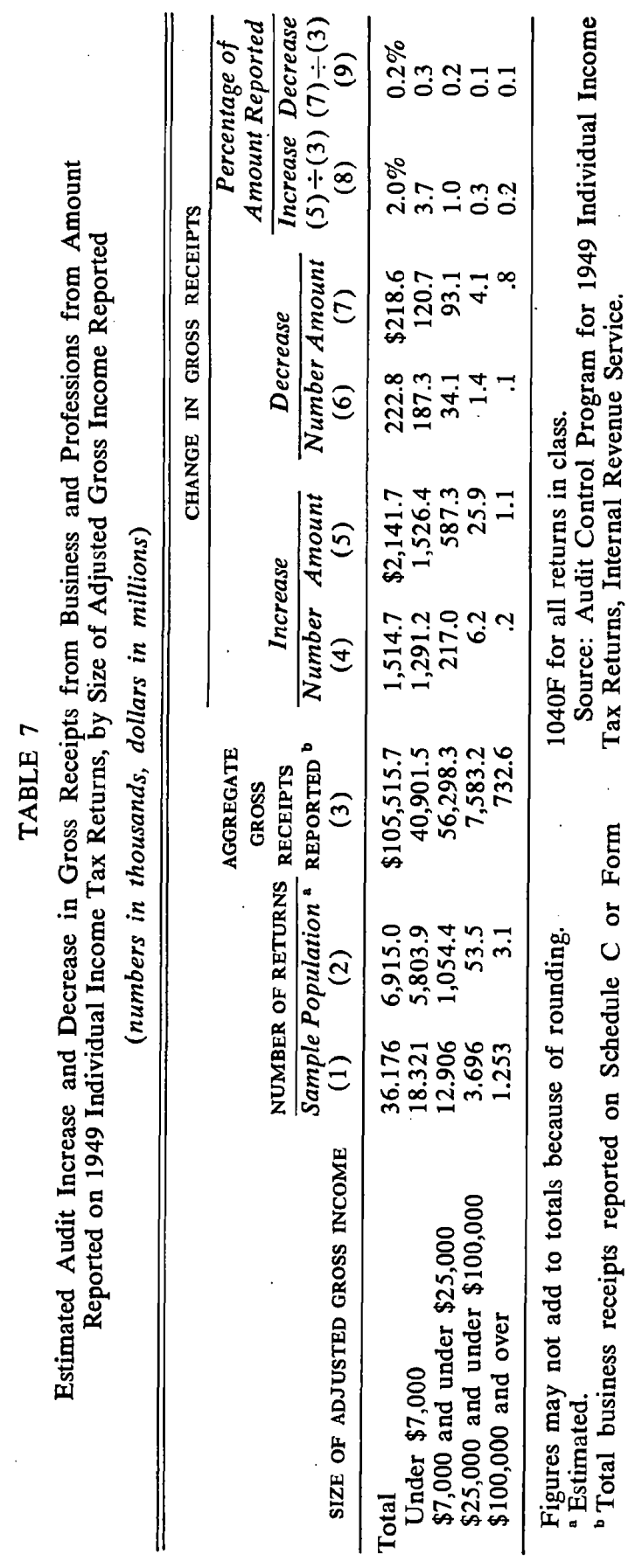




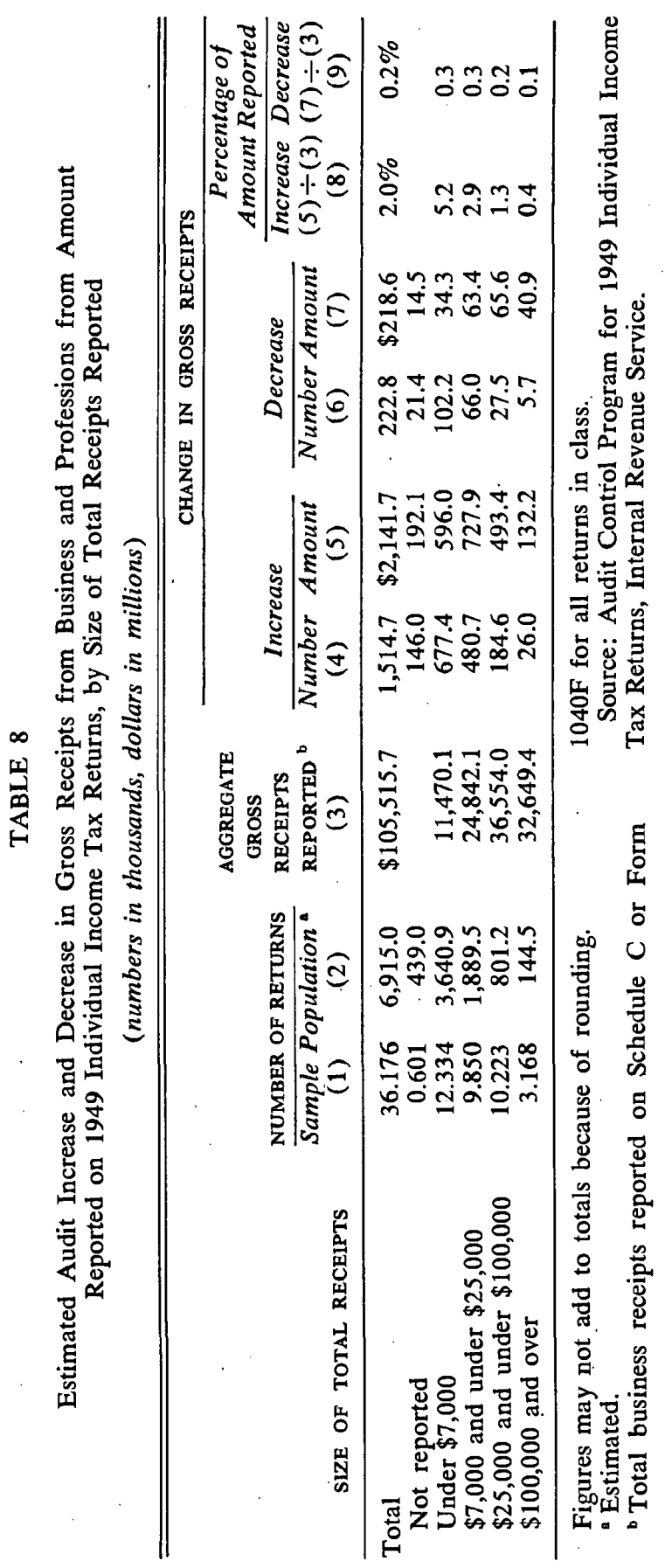




\section{TABLE 9}

Estimated Number of 1949 Corporation Income Tax Returns Filed by Corporations with Assets under $\$ 250,000,{ }^{\mathfrak{a}}$ by Region

(numbers in thousands)

\begin{tabular}{|c|c|c|c|}
\hline \multirow[b]{2}{*}{ UNITED STATES AND REGIONS } & \multirow{2}{*}{$\begin{array}{l}\text { NUMBER } \\
\text { OF } \\
\text { RETURNS }\end{array}$} & \multicolumn{2}{|c|}{$\begin{array}{l}\text { NUMBER WITH CURRENT } \\
\text { YEAR }^{\text {b }}\end{array}$} \\
\hline & & Net Income & Net Loss \\
\hline United States & 507.2 & 295.2 & 211.9 \\
\hline Atlanta & 40.5 & 25.3 & 15.2 \\
\hline Boston & 47.5 & 26.5 & 21.0 \\
\hline Chicago & 57.3 & 34.2 & 23.1 \\
\hline Cincinnati & 52.0 & 33.1 & 18.9 \\
\hline Dallas & 25.2 & 15.2 & 10.0 \\
\hline New York & 132.9 & 73.3 & 59.6 \\
\hline Omaha & 43.2 & 28.4 & 14.9 \\
\hline Philadelphia & 64.5 & 37.4 & 27.0 \\
\hline San Francisco & 44.1 & 22.0 & 22.1 \\
\hline
\end{tabular}

Figures may not add to totals because of rounding.

a Includes corporations filing returns with incomplete or no balance sheets.

bstimated; corporations reporting net income or net loss before net operating loss deduction in the current year.

Source: Audit Control Program for 1949 Corporation Income Tax Returns Filed by Corporations with Assets under \$250,000, Internal Revenue Service.

TABLE 10

Estimated Audit Increase and Decrease in Net Income from Amount Reported by Corporations with Assets under $\$ 250,000^{*}$ Reporting Current Year Net Income on 1949 Corporation Income Tax Returns, by Region

(numbers in thousands, dollars in millions)

\begin{tabular}{|c|c|c|c|c|c|c|}
\hline \multirow{3}{*}{$\begin{array}{l}\text { UNITED STATES } \\
\text { AND REGIONS }\end{array}$} & \multirow{3}{*}{$\begin{array}{l}\text { NUMBER } \\
\text { OF } \\
\text { RETURNS }\end{array}$} & \multirow{3}{*}{$\begin{array}{l}\text { NET INCOME } \\
\text { REPORTED }\end{array}$} & \multirow{2}{*}{\multicolumn{2}{|c|}{$\begin{array}{l}\text { CHANGE IN } \\
\text { Increase }\end{array}$}} & \multirow{2}{*}{\multicolumn{2}{|c|}{$\frac{\text { NET INCOME }}{\text { Decrease }}$}} \\
\hline & & & & & & \\
\hline & & & Number & Amount & Number & Amount \\
\hline United States & 295.2 & $\$ 2,271.6$ & 141.0 & $\$ 249.2$ & 17.3 & $\$ 24.1$ \\
\hline Atlanta & 25 & 23 & 10.4 & 21.2 & 1.9 & 4.8 \\
\hline Boston & 26.5 & 176.7 & 15.6 & 27.9 & 1.9 & 1.5 \\
\hline Chicago & 34.2 & 270.6 & 15.1 & 32.5 & 2.2 & 3.3 \\
\hline Cincinnati & $33.1^{\circ}$ & 302.5 & 14.1 & 21.7 & 2.0 & 5.1 \\
\hline Dallas & 15.2 & 145.8 & 6.0 & 13.8 & 0.9 & 0.7 \\
\hline New York & 73.3 & 406.3 & 41.8 & 59.3 & 3.0 & 2.1 \\
\hline Omaha & 28.4 & 244.9 & 10.8 & 15.5 & 2.4 & 2.4 \\
\hline Philadelphia & 37.4 & 256.3 & 19.3 & 33.9 & 1.6 & 1.3 \\
\hline San Francisco & 22.0 & 231.0 & 8.0 & 23.3 & 1.4 & 2.9 \\
\hline
\end{tabular}

Figures may not add to totals because of rounding.

a Includes corporations filing returns with incomplete or no balance sheets.

${ }^{b}$ Estimated; corporations reporting net income before net operating loss deduction in the current year.

Source: Audit Control Program for 1949 Corporation Income Tax Returns Filed by Corporations with Assẹts under $\$ 250,000$, Internal Revenue Service. 


\section{TABLE 11}

Estimated Audit Increase and Decrease in Net Loss from Amount Reported by Corporations

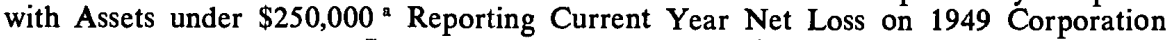

Income Tax Returns, by. Region

(numbers in thousands, dollars in millions)

\begin{tabular}{|c|c|c|c|c|c|c|}
\hline \multirow{3}{*}{$\begin{array}{l}\text { UNITED STATES } \\
\text { AND REGIONS }\end{array}$} & \multirow{3}{*}{$\begin{array}{c}\text { NUMBER } \\
\text { OF RETURNS }\end{array}$} & \multirow{3}{*}{$\begin{array}{l}\text { AMOUNT OF } \\
\text { NET LOSS } \\
\text { REPORTED }\end{array}$} & \multicolumn{4}{|c|}{ CHANGE IN NET LOSS } \\
\hline & & & \multicolumn{2}{|c|}{ Increase } & \multicolumn{2}{|c|}{ Decrease } \\
\hline & & & Number & $\overline{A m o u n t}$ & Number & Amount \\
\hline United States & 211.9 & $\$ 1,069.8$ & 10.9 & $\$ 21.7$ & 85.5 & $\$ 195.3$ \\
\hline Atlanta & 15.2 & 82.3 & 0.9 & 0.6 & 6.0 & 17.1 \\
\hline Boston & 21.0 & 88.6 & 1.2 & 1.4 & 8.5 & 14.8 \\
\hline Chicago & 23.1 & 152.0 & 1.4 & 2.7 & 8.2 & 18.2 \\
\hline Cincinnati & 18.9 & 97.8 & 1.2 & 1.0 & 8.0 & 14.3 \\
\hline Dallas & 10.0 & 51.7 & 0.5 & 0.7 & 3.4 & 6.2 \\
\hline New York & 59.6 & 255.2 & 2.5 & 3.5 & 29.7 & 67.3 \\
\hline Omaha & 14.9 & 80.6 & 1.1 & 0.8 & 4.0 & 11.8 \\
\hline Philadelphia & 27.0 & 122.6 & 0.9 & 1.7 & 12.1 & 21.9 \\
\hline San Francisco & 22.1 & 139.2 & 1.4 & 9.2 & 5.7 & 23.7 \\
\hline
\end{tabular}

Figures may not add to totals because of rounding.

- Includes corporations filing returns with incomplete or no balance sheets.

b Estimated; corporations reporting net loss before net operating loss deduction in the current year.

Source: Audit Control Program for 1949 Corporation Income Tax Returns Filed by Corporations with Assets under $\$ 250,000$, Internal Revenue Service.

\section{TABLE 12}

Estimated Audit Increase and Decrease in Income Items from Amount Reported by Corporations with Assets under $\$ 250,000^{\circ}$ Reporting Current Year Net Income on 1949 Corporation Income Tax Returns, by Income Item

(dollars in thousands)

\begin{tabular}{|c|c|c|c|c|c|}
\hline \multirow[b]{3}{*}{ INCOME ITEM } & \multirow{3}{*}{$\begin{array}{l}\text { NUMBER } \\
\text { OF ITEMS }\end{array}$} & \multicolumn{4}{|c|}{ CHANGE IN INCOME ITEM } \\
\hline & & \multicolumn{2}{|c|}{ Increase } & \multicolumn{2}{|c|}{ Decrease } \\
\hline & & Number & Amount & Number & Amount \\
\hline Total & 34,911 & 26,533 & $\$ 77,016$ & 8,378 & $\$ 31,314$ \\
\hline Gross sales and receipts & 14,724 & 11,372 & 47,375 & 3,352 & 20,235 \\
\hline Net long term capital gain & 4,420 & 2,661 & 6,612 & 1,759 & 2,943 \\
\hline Rents & 3,557 & 3,008 & 2,731 & 549 & 400 \\
\hline Interest & 3,196 & 2,786 & 1,461 & 410 & 390 \\
\hline Net gains from sale or & & & & & \\
\hline exchange of other property & 2,227 & 1,187 & 2,076 & 1,040 & 1,311 \\
\hline Dividends & 303 & 187 & 6,600 & 116 & 22 \\
\hline Net short term capital gain & 194 & 103 & 92 & 91 & 224 \\
\hline Royalties & 184 & 48 & 100 & 136 & 2,258 \\
\hline Other & 6,106 & 5,181 & 9,968 & 925 & 3,532 \\
\hline
\end{tabular}

Figures may not add to totals because of rounding.

" Includes corporations filing returns with incomplete or no balance sheets.

bstimated; corporations reporting net income before net operating loss deduction in the current year.

Source: Audit Control Program for 1949 Corporation Income Tax Returns Filed by Corporations with Assets under $\$ 250,000$, Internal Revenue Service. 
TABLE 13

Estimated Audit Increase and Decrease in Income Items from Amount Reported by Corporations with Assets under $\$ 250,000^{a}$ Reporting Current Year Net Loss on 1949 Corporation Income Tax Returns, by Income Item

(dollars in thousands)

\begin{tabular}{|c|c|c|c|c|c|}
\hline \multirow[b]{3}{*}{ INCOME ITEM } & \multirow{3}{*}{$\begin{array}{l}\text { NUMBER } \\
\text { OF ITEMS }\end{array}$} & \multicolumn{4}{|c|}{ CHANGE IN INCOME ITEM } \\
\hline & & \multicolumn{2}{|c|}{ Increase } & \multicolumn{2}{|c|}{ Decrease } \\
\hline & & Number & Amount & Number & Amount \\
\hline Total & 23,543 & 19,284 & $\$ 66,847$ & 4,259 & $\$ 14,150$ \\
\hline Gross sales and receipts & 12,893 & 10,627 & 50,161 & 2,266 & 9,332 \\
\hline Rents & 2,502 & 2,119 & 3,718 & 383 & 376 \\
\hline Net long term capital gain & 1,927 & 1,503 & 4,982 & 424 & 1,277 \\
\hline Net gains from sale or & & & & & \\
\hline exchange of other property & 1,568 & 1,176 & 1,573 & 392 & 1,111 \\
\hline Interest & 1,406 & 1,220 & 398 & 186 & 13 \\
\hline Net short term capital gain & 262 & 247 & 1,363 & 15 & 7 \\
\hline Dividends & 46 & 15 & 11 & 31 & 12 \\
\hline Other & 2,939 & 2,377 & 4,641 & 562 & 2,021 \\
\hline
\end{tabular}

Figures may not add to totals because of rounding.

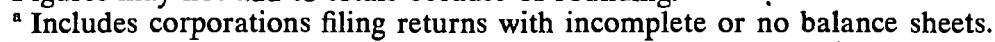

${ }^{b}$ Estimated; corporations reporting net loss before net operating loss deduction in the current year.

Source: Audit Control Program for 1949 Corporation Income Tax Returns Filed by Corporations with Assets under \$250,000, Internal Revenue Service.

\section{TABLE 14}

Estimated Audit Increase and Decrease in Deduction Items from Amount Reported by Corporations with Assets under $\$ 250,000^{a}$ Reporting Current Year Net Income on 1949 Corporation Income Tax Returns, by Deduction Item (dollars in thousands)

\begin{tabular}{|c|c|c|c|c|c|}
\hline \multirow[b]{3}{*}{ DEDUCTION ITEM } & \multirow{3}{*}{$\begin{array}{l}\text { NUMBER } \\
\text { OF ITEMS }\end{array}$} & \multicolumn{4}{|c|}{ CHANGE IN DEDUCTION ITEM } \\
\hline & & \multicolumn{2}{|c|}{ Increase } & \multicolumn{2}{|c|}{ Decrease } \\
\hline & & Number & $\overline{\text { Amount }}$ & Number & $\overline{\text { Amount }}$ \\
\hline Total & 295,247 & 81,530 & $\$ 42,003$ & 213,717 & $\$ 221,398$ \\
\hline Taxes & 61,827 & 30,571 & 6,408 & 31,256 & 9,057 \\
\hline Depreciation & 58,871 & 24,202 & 6,449 & 34,669 & 30,603 \\
\hline \multicolumn{6}{|l|}{ Cost of goods sold and } \\
\hline operations & 25,184 & 4,026 & 14,502 & 21,158 & 52,628 \\
\hline Contributions or gifts & 20,263 & 11,239 & 760 & 9,024 & 1,208 \\
\hline Repairs & 18,699 & 747 & 352 & 17,952 & 17,239 \\
\hline Compensation of officers & 13,921 & 796 & 3,434 & 13,125 & 29,368 \\
\hline Interest & 7,794 & 1,882 & 718 & 5,912 & 4,780 \\
\hline Bad debts & 7,590 & 728 & 1,203 & 6,862 & 8,190 \\
\hline Salaries and wages & 3,653 & 767 & 506 & 2,886 & 3,987 \\
\hline Advertising & 3,216 & 137 & 157 & 3,079 & 1,319 \\
\hline Rent & 2,187 & 364 & 136 & 1,823 & 1,806 \\
\hline \multirow{3}{*}{$\begin{array}{l}\text { Net loss from sale or ex- } \\
\text { change of other property } \\
\text { Depletion }\end{array}$} & & & & & \\
\hline & 1,964 & 1,017 & 3,277 & 947 & 928 \\
\hline & 981 & 502 & 484 & 479 & 939 \\
\hline
\end{tabular}

continued on next page 
TABLE 14 , continued

\begin{tabular}{|c|c|c|c|c|c|}
\hline \multirow[b]{3}{*}{ DEDUCTION ITEM } & \multirow{3}{*}{$\begin{array}{l}\text { NUMBER } \\
\text { OF ITEMS }\end{array}$} & \multicolumn{4}{|c|}{ CHANGE IN DEDUCTION ITEM } \\
\hline & & \multicolumn{2}{|c|}{ Increase } & \multicolumn{2}{|c|}{ Decrease } \\
\hline & & Number & $\overline{A m o u n t}$ & Number & Amount \\
\hline $\begin{array}{l}\text { Contributions under pension, } \\
\text { annuity, stock bonus, etc. } \\
\text { plans }\end{array}$ & 432 & 36 & 24 & 396 & 590 \\
\hline $\begin{array}{l}\text { Losses by fire, storm, etc. } \\
\text { Other, including amortization }\end{array}$ & 180 & 18 & 4 & 162 & 185 \\
\hline emergency facilities & 68,485 & 4,498 & 3,589 & 63,987 & 58,569 \\
\hline
\end{tabular}

Figures may not add to totals because of rounding.

"Includes corporations filing returns with incomplete or no balance sheets.

b Estimated; corporations reporting net income before net operating loss deduction in the current year.

Source: Audit Control Program for 1949 Corporation Income Tax Returns Filed by Corporations with Assets under $\$ 250,000$, Internal Revenue Service.

\section{TABLE 15}

Estimated Audit Increase and Decrease in Deduction Items from Amount Reported by Corporations with Assets under $\$ 250,000^{\circ}$ Reporting Current Year Net Loss on 1949 Corporation Income Tax Returns, by Deduction Item

(dollars in thousands)

\begin{tabular}{|c|c|c|c|c|c|}
\hline \multirow[b]{3}{*}{ DEDUCTION ITEM } & \multirow{3}{*}{$\begin{array}{l}\text { NUMBER } \\
\text { OF ITEMS }\end{array}$} & \multicolumn{4}{|c|}{ CHANGE IN DEDUCTION ITEM } \\
\hline & & \multicolumn{2}{|c|}{ Increase } & \multicolumn{2}{|c|}{ Decrease } \\
\hline & & Number & $\overline{A m o u n t}$ & Number & Amount \\
\hline Total & 179,272 & 39,939 & $\$ 41,863$ & 139,333 & $\$ 162,741$ \\
\hline Depreciation & 32,461 & 14,616 & 10,025 & 17,845 & 15,462 \\
\hline Taxes & 25,960 & 9,192 & 1,548 & 16,768 & 4,877 \\
\hline \multicolumn{6}{|l|}{ Cost of goods sold and } \\
\hline operations & 20,657 & 3,496 & 16,326 & 17,161 & 43,481 \\
\hline Contributions or gifts & 17,506 & 2,226 & 97 & 15,280 & 1,672 \\
\hline Repairs & 9,319 & 644 & 391 & 8,675 & 7,613 \\
\hline Compensation of officers & 8,601 & 587 & 1,486 & 8,014 & 16,031 \\
\hline Interest & 5,903 & 1,488 & 392 & 4,415 & 3,095 \\
\hline Bad debts & 4,045 & 676 & 1,212 & 3,369 & 10,064 \\
\hline Salaries and wages & 3,584 & 1,224 & 1,925 & 2,360 & 1,604 \\
\hline Advertising & 2,383 & 255 & 42 & 2,128 & 1,089 \\
\hline Rent & 2,337 & 268 & 204 & 2,069 & 3,330 \\
\hline \multicolumn{6}{|l|}{ Net loss from sale or ex- } \\
\hline change of other property & 2,327 & 930 & 4,101 & 1,397 & 12,804 \\
\hline Depletion & 313 & 49 & 45 & 264 & 1,171 \\
\hline Losses by fire, storm, etc. & 214 & 18 & 7 & 196 & 430 \\
\hline \multicolumn{6}{|l|}{ Contributions under pension, } \\
\hline plans & 132 & 49 & 4 & 83 & 275 \\
\hline \multicolumn{6}{|l|}{ Other, including amortization } \\
\hline emergenc & 43,530 & 4,221 & 4,058 & 39,309 & 39,745 \\
\hline
\end{tabular}

Figures may not add to totals because of rounding.

a Includes corporations filing returns with incomplete or no balance sheets.

b Estimated; corporations reporting net loss before net operating loss in the current year.

Source: Audit Control Program for 1949 Corporation Income Tax Returns Filed by Corporations with Assets under $\$ 250,000$, Internal Revenue Service. 


\section{Appendix: Sampling and Methods of Estimation}

\section{INDIVIDUAL INCOME TAX RETURNS}

1. Population. The population studied consisted of timely filed individual income tax returns for the year 1949. Taxpayers were required to file their returns with the then "Collector of Internal Revenue" for the district in which they resided. Each collector entered a "serial number" on each return filed with him. The use of collection district plus serial number provides a unique identification for each return.

2. Frame. The frame described in section 1 was partitioned into broad classes as follows:

.01 Form $1040 \mathrm{~A}$ returns

.02 Lower income returns on Form 1040, described as "collectors' returns"

.03 Higher income returns on Form 1040, described as "agents' returns"

.031 Under $\$ 25,000$

$.032 \$ 25,000$ up to $\$ 100,000$

$.033 \$ 100,000$ and over

3. Sampling rates. The rates allocated to each partition of the frame were as follows:

$\begin{array}{lllc} & \text { Partition } & \text { Class of Return } & \begin{array}{c}\text { Sampling Rate } \\ (\text { per cent })\end{array} \\ .01 & \text { Form 1040A } & \text { all } & 0.03 \\ .02 & \text { Collectors' 1040: } & \text { nonbusiness } & 0.04 \\ & & \text { nonfarm business } & 0.50 \\ .03 & \text { Agents' 1040: } & \text { farm } & 0.15 \\ .031 & \text { Under } \$ 25,000 & \text { nonbusiness } & 0.30 \\ .032 & \$ 25,000 \text { up to } \$ 100,000 & \text { business } & \text { nonbusiness } \\ & & \text { business } & 1.20 \\ 0.33 & \$ 100,000 \text { and over } & \text { nonbusiness } & 5.00 \\ & & \text { business } & 20.00 \\ & & & 40.00\end{array}$

Note: In the .03 partitions, returns reporting farm income are included with business.

4. Method of selection. Serial numbers have at least four digits. The sampling rates allocated above were approximated by selecting returns with the following digit combinations:

\begin{tabular}{|c|c|c|c|c|c|}
\hline \multicolumn{2}{|c|}{ Partition and Class } & $\begin{array}{l}\text { Thou- } \\
\text { sands }\end{array}$ & $\begin{array}{l}\text { Hun- } \\
\text { dreds }\end{array}$ & Tens & Units \\
\hline \multirow[t]{3}{*}{$\begin{array}{l}.01 \\
.02\end{array}$} & $\begin{array}{l}\text { Form 1040A } \\
\text { Collectors' 1040: }\end{array}$ & 0 & 0 & $0,1,2$ & 0 \\
\hline & Nonbusiness & $\begin{array}{l}0 \\
0\end{array}$ & $\begin{array}{l}0 \\
0\end{array}$ & $\begin{array}{l}0 \\
4\end{array}$ & $\begin{array}{l}0,1 \\
8,9\end{array}$ \\
\hline & Nonfarm business & 0 & 0 & $0,1,2,3,4$ & all \\
\hline
\end{tabular}

Note: This section of the appendix was prepared by C. B. Fine. 
M A T CHING A N D QUALITY STUDIES

Partition and Class

Farm

.03 Agents' 1040:

.031 Under $\$ 25,000$ :

Nonbusiness

Business
Thou- Hun-

sands dreds

$\left\{\begin{array}{l}0 \\ 0 \\ 0\end{array}\right.$

$\left\{\begin{array}{l}\text { all } \\ \text { all } \\ \text { all }\end{array}\right.$

0

0

0

.032

.033
$\$ 25,000$ up to $\$ 100,000$ :

Nonbusiness

Business

$\$ 100,000$ and over:

Nonbusiness

Business

$\begin{array}{cccc}\text { all } & \text { all } & 0,2 & 0 \\ \text { all } & \text { all } & 0,2,4,6,8 & 0 \\ & & & \\ \text { all } & \text { all } & \text { all } & 0,5 \\ \text { all } & \text { all } & \text { all } & 0,3,5,7\end{array}$

5. Systematic nature of sample. It is apparent from the above description that the sample is systematic as well as stratified. Returns were numbered by the collector as an aid to processing the returns in the ordinary business of the Internal Revenue Service. Usually a working group consists of 100 returns, called a "block" and consecutively numbered from 00 to 99 . Further, "series" are reserved for similar groups of returns. Usually a series will start with a number ending in four zeros, hence a series with few blocks will be sampled more heavily than one with many blocks if returns with " 00 " block numbers are chosen. Similarly, a block may contain less than 100 returns. For these reasons, the use of low digits may result in sampling in excess of the allocated rate.

To the extent that characteristics correlated with tax change are used by the collector, the sampling system described above will be more efficient than random sampling. ${ }^{11}$

6. Method of estimation. Estimates were derived from each partition separately, viz., $.01, .02, .031, .032$, and .033 for each collection district. The general formula used was

$$
X^{\prime}=\frac{N}{n} \sum_{j=1}^{3} \frac{1}{r_{j}} \sum_{k=1}^{n_{j}} x_{j k}
$$

where $N=$ number of returns in the specified partition of the frame

$$
n=\sum_{j=1}^{3} \frac{n_{j}}{r_{j}}
$$

${ }^{21}$ See William G. Madow and Lillian H. Madow, "On the Theory of Systematic Sampling, I," Annals of Mathematical Statistics, March 1944, pp. 1-24; Lillian H. Madow, "Systematic Sampling and its Relation to Other Sampling Designs," Journal of the American Statistical Association, June 1945, pp. 204-217; and William G. Cochran, "Relative Accuracy of Systematic and Stratified Random Samples for a Certain Class of Populations," Annals of Mathematical Statistics, June 1946, pp. 164-177. 
$j=1$ if nonbusiness

2 if nonfarm business

3 if farm

$n_{j}=$ number of sample returns in the $j^{\text {th }}$ class

$r_{j}=$ sampling rate allocated to $j^{\text {th }}$ class

$k=1,2, \ldots, n_{j}$

$x_{j k}=$ the value of a characteristic for the $j k^{\text {th }}$ return.

The individual estimate for a single partition was then added within the size group, e.g. Forms 1040A, to obtain a total for all collection districts. In this case, the general formula can be simplified by omitting the $j$ summation to

$$
X^{\prime}=\frac{N}{n} \sum_{k=1}^{n} x_{k}
$$

For example, the partition Alabama (.02) collectors' 1040's contained the following sampled returns:

\begin{tabular}{lccc}
\multicolumn{1}{c}{ Class } & $\begin{array}{c}\text { Number of } \\
\text { Returns } \\
\text { in Sample }\end{array}$ & $\begin{array}{c}\text { Allocated } \\
\text { Rate }\end{array}$ & $\begin{array}{c}\text { Weight per } \\
\text { Sampled } \\
\text { Return }\end{array}$ \\
Nonbusiness & 134 & .0004 & 2,456 \\
Nonfarm business & 176 & .0050 & 196 \\
Farm & 36 & .0015 & 655
\end{tabular}

A total of 387,276 collectors' Form 1040 returns were filed in Alabama for 1949. The computation was as follows:

$$
\begin{gathered}
\frac{134}{.0004}+\frac{176}{.005}+\frac{36}{.0015}=394,200 \\
\frac{387,276}{394,200} \times \frac{1}{.0004} \doteq 2,456 \\
\frac{387,276}{394,200} \times \frac{1}{.0050} \doteq 196 \\
\frac{387,276}{394,200} \times \frac{1}{.0015} \doteq 655
\end{gathered}
$$

7. General size of sample. While space does not permit specifying the size of the sample for each partition and class of return, the following table summarizes the partitions for all collection districts combined:

Returns in Sample

.01 Form 1040A:

.02 Collectors' 1040:

.031 Agents' under $\$ 25,000$ :

18,000

.032 Agents $\$ 25,000$ up to $\$ 100,000$ :

.033 Agents $\$ 100,000$ and over:

3,200 


\section{CORPORATION INCOME TAX RETURNS}

The Audit Control Program for 1949 included a sample of corporation income tax returns as filed, with assets of $\$ 250,000$ or less, and returns with incomplete or no balance sheets. It was estimated that resources were available to process a sample of 15,000 returns; actually 16,035 returns were selected in the sample.

All corporation income tax returns filed for the tax year 1949 were tabulated to obtain the data for Statistics of Income, Part 2. The total number of returns was about 650,000 . The restricted population from which the audit control sample was selected included slightly more than 500,000 of these returns.

The sample design employed was of the stratified random type with optimum allocation. The population from which this sample was selected was stratified by 4 asset classes and by 41 industry groups making a total of 164 strata. The distribution of the population by the asset classes as well as the distribution of the sample, and the corresponding weights, follow:

\begin{tabular}{|c|c|c|c|}
\hline Strata. & $\begin{array}{c}\text { Sample } \\
\text { Size }\end{array}$ & $\begin{array}{c}\text { Population } \\
\text { Size }\end{array}$ & Weight \\
\hline Retail furriers and luggage stores & 624 & 678 & 1.0865 \\
\hline Asset size: & & & \\
\hline Under $\$ 50,000$ & 2,681 & 242,397 & 90.4129 \\
\hline$\$ 50,000-\$ 100,000$ & 3,248 & 99,728 & 30.7044 \\
\hline$\$ 100,000-\$ 250,000$ & 5,656 & 104,155 & 18.4149 \\
\hline No balance sheet & 3,826 & 60,216 & $15.4047^{\circ}$ \\
\hline Total & 16,035 & 507,174 & \\
\hline
\end{tabular}

a 16 returns were weighted by 90.4129 and 5 returns by 30.7044

A serious problem arose in connection with the sampling of corporation income tax returns because these returns were not only assembled in bundles of various sizes but they moved through a routine of processing as a continuous flow. It was impossible therefore to accumulate all of the income tax returns in a file and to design a sampling method applicable to a file of returns. The problem of counting all returns and identifying the sample returns in 164 strata was solved by using decks of punch cards which were racked in special built sampling boxes. ${ }^{12} \mathrm{~A}$ separate deck of punch cards was prepared for each of the 164 strata. These cards were punched with the following codes: asset size codes, the industry code, and a sample code to indicate whether the card report was a sample or nonsample return. A punch card was drawn from the boxes for each tax return. White cards were used for nonsample returns while red cards were used to designate the sample returns. The red cards were inter-spaced with the white cards with evenly spaced intervals cor-

Note: This section of the appendix was prepared by A. C. Rosander.

${ }^{19}$ A detailed description of this technique and its operation appears in a paper by Rosander, Blythe, and Johnson entitled "Sampling 1949 Corporation Income Tax Returns," Journal of the American Statistical Association, June 1951, pages 233-241. 
responding to the proper sampling ratios. The punch cards drawn from the boxes were tabulated daily by asset class and industry. In this way complete control was maintained over the selection of the sample in each of the strata.

Although the sampling procedure gave population counts for the various strata and therefore could be used as a basis of validating the weights, actually the weights were derived by using the Statistics of Income totals for each of the four asset classes. (There were only slight differences between the population as estimated from the sample and the population arrived at from the 100 per cent tabulation of corporation income tax returns.) As the accompanying table shows, the original weights for the four strata of $90,30,18$, and 15 were revised only slightly in our final calculations. The weights shown in the accompanying table by asset classes were applied to all the sample data including counts and money values in each of the strata to which that weight applied.

\section{O M M E T}

\section{Charles F. Schwartz, office of business economics, DEPARTMENT OF COMMERCE}

The paper by Marius Farioletti is a most valuable contribution containing audit information now made public through the cooperation of the Internal Revenue Service and concise explanations of the purpose, scope, and procedure of the 1949 Audit Control Program. He makes clear that the estimates produced by the ACP represent not all the actual errors but those that would be found if all returns were audited with about the same experience and time factors, concluding, "No one really knows the size of the difference between errors disclosed and errors made."

Farioletti is wholly right, and his statement of the definition of error in the ACP is impeccable. Still, one is prone to wonder how experienced the investigators were who worked on the 1949 study and whether adequate time was made available to them. If the answers to such questions were favorable - as I believe they would be-greater confidence could be attached to the audit estimates than is permitted by a strict interpretation of Farioletti's statement.

\section{CONTRIBUTION TO NATIONAL INCOME ESTIMATION}

For our National Income Division estimates of family personal income by size classes, Tables 2 to 4,7 , and 8 will prove useful, but certain additional information is needed. For instance, Table 4 shows the amount of adjusted gross income disclosed by audit classified by the type of income representing the major source of 
error. We need to know directly, however, the total amounts of interest, rents, dividends, and so forth disclosed by audit for each adjusted gross income bracket, not just for the under $\$ 10,000$ class. Also Table 7 would be more useful for our work if the audit changes shown related to net profit from business, instead of to gross receipts from business, and if farm income were tabulated separately.

For our estimates of entrepreneurial nonfarm income included in the national income and personal income series we have used IRS tax-return tabulations extensively in preparing benchmarks for a number of years since 1939. These tabulations are made from unaudited returns, with the amounts of income taken as directly reported by taxpayers. To adjust the tabulations for understatement of income was at first a matter of guesswork and therefore unsatisfactory, particularly on an industry basis. For preparing National Income Supplement, 1954, however, Farioletti kindly made available to us the unpublished audit data shown in his Table 5. This essential information shows the amount of additional net income disclosed by audit of a representative sample of returns.

But this information covers only sole proprietorships, not partnerships, for the single year 1949. The 1949 sample audit of individual proprietorships, valuable as it is, had to be used to make an audit correction, industry by industry, of nonfarm proprietors' income over the whole period since 1929. Audit information of the type shown in Table 5, covering partnerships as well, would be highly desirable to have on at least a periodic basis.

The corporate profits component of national income is also based on IRS tax-return tabulations with the same problem of adjusting the original, unaudited returns for understatement. Since direct estimates of the amount of additional corporate profits that would be disclosed by a full audit have never been available, we have had to work with data on additional assessments of tax liability (by methods described in the National Income Supplement). The procedure involved a complex problem of timing pattern, difficulties in the treatment of deficit corporations, and of selecting an effective tax rate by which to raise tax liabilities to an estimate of total net profit. For the past few years the information on tax liabilities that was used in this method has not been available from the IRS, and we have had to extend the corporate profits audit adjustment on an informal, judgmental basis.

Farioletti's tables showing audit changes for corporations will prove helpful to us, but their immediate impact is to whet the appetite for similar information on corporations with assets over $\$ 250,000$. We recognize, of course, that auditing returns for large 
corporations is a long drawn out process that could not have been accomplished by the 1949 study.

That students of national income need much more information on audit changes is simply the familiar situation of the statistical demand exceeding the available resources. My strong hope is that some means can be found for making additional tabulations from the audit programs already completed, and that audit studies can be conducted on a periodic basis with an eye to the needs of statisticians.

\section{Joseph A. Pechman, committee for ECONOMIC DEVELOPMENT}

Farioletti's paper will be extremely helpful to national income estimators as a source of information on underreporting of income by individuals and married couples on their tax returns. The unaudited data tabulated by the Internal Revenue Service in Statistics of Income are used not only to estimate the movement of specific types of income receipts but also to approximate the distribution of income by income levels. Income statisticians have, of course, been aware that, on balance, taxpayers tend to understate their incomes on tax returns, but they have had to use secondary and less desirable sources to supplement Statistics of Income to correct for this underreporting. Although we need to know a great deal more, the information provided thus far from the 1949 Audit Control Program throws considerable light on the so-called gap between the official Department of Commerce estimate of personal income and the amount of income (i.e. adjusted gross income) reported on individual income tax returns.

In the years 1948-1952, adjusted gross income reported on tax returns fell short of personal income by an average of almost $\$ 50$ billion, or about 20 per cent. Actually, much of this "unadjusted gap" can be accounted for by known conceptual differences between the two totals. On the one hand, numerous receipts in personal income are not included in adjusted gross income, such as transfer payments, other labor income, income in kind, imputed interest, and nontaxable military pay and allowances. On the other, many receipts subject to tax are excluded from personal income, including employee contributions for social insurance, capital gain, annuities, and incomes of residents of Alaska and Hawaii. Most of these adjustments can be estimated fairly accurately, so that we can go fairly readily from personal income to adjusted gross income. The detailed adjustments for 1949-the year for which 
the new data from the ACP are now available-are shown in Table 1.1

Personal income amounted to $\$ 206.8$ billion in $1949, \$ 46.2$ billion more than the adjusted gross income reported on taxable and nontaxable individual income tax returns. As indicated in Table 1, after correction of personal income for conceptual dif-

${ }^{1}$ Data for the years 1948 through 1956 are shown in my paper, "Erosion of the Individual Income Tax," National Tax Journal, March 1957, Table 1, p. 4.

TABLE 1

Adjustments of Department of Commerce Estimates of Personal Income to Arrive at Adjusted Gross Income, 1949

(billions of dollars)

\begin{tabular}{lr}
\hline \hline \multicolumn{1}{c}{ Item } & Amount \\
\hline Personal income & 206.8 \\
Portion of personal income not included in adjusted gross income & 28.7 \\
1. Transfer payments (except fees and military retirement pay) & 12.4 \\
2. Other labor income (except pay of military reservists) & 2.7 \\
3. Food and fuel produced and consumed on farms & 2.2 \\
4. Imputed gross rental value of tenant-occupied farm houses & 0.4 \\
5. Other personal income in kind except services of financial inter- & \\
mediaries & 5.1 \\
6. Noncorporate nonfarm inventory valuation adjustment & 0.5 \\
7. Value of change in farm inventories & -0.9 \\
8. Imputed interest & 4.0 \\
9. Nontaxable military pay and allowances & 0.4 \\
10. Accrued interest on U. S. government bonds & 0.6 \\
11. Tax-exempt interest & 0.3 \\
12. Fiduciary income (other than capital gains) not distributed to & \\
individuals & 0.6 \\
13. Property income of nonprofit organizations & 0.4 \\
Portion of adjusted gross income not included in personal income & 5.6 \\
14. Employee contributions for social insurance & 2.2 \\
15. Net gains from sale of assets reported on individual income tax & \\
returns & 1.5 \\
16. Adjusted gross income of residents of Alaska and Hawaii reported & \\
on individual income tax returns & 0.7 \\
17. Miscellaneous income (except other income on Form 1040A) & \\
reported on individual income tax returns & 1.0 \\
18. Annuities and pensions reported on individual income tax returns & 0.4 \\
19. Deductions for net operating loss carryover and depletion & -0.3 \\
Total adjustment for conceptual differences (line 1-19) & 23.1 \\
Estimated adjusted gross income of taxable and nontaxable individuals & 183.7 \\
\hline
\end{tabular}

Figures are rounded and will not necessarily add to totals.

\section{Source}

Lines 1, 2, 3, 5, 6, 7, 8, and 14-Dept. of Commerce.

Lines 10 and 11-Estimates based on data in the Annual Report of the. Secretary of the Treasury.

Lines 12, 15, 16, 17, and 18-Statistics of Income for 1948, Part 1.

Lines 4, 9, 13, and 19-Based on data supplied by Selma F. Goldsmith. 
ferences, adjusted gross income should total $\$ 183.7$ billion. Thus roughly half of the "unadjusted gap" is accounted for by differences in concept. The remaining gap of $\$ 23$ billion is the discrepancy to be explained.

Three major items enter into this gap: (1) the incomes of persons not required to file returns, (2) underreporting of income by persons who do file, and (3) errors in the personal income estimates. If the first two items could be measured with certainty, we could verify the official estimates of personal income. Farioletti supplied a few figures covering the second item, and it is of interest to see how much of the gap we can explain with them.

His estimates of underreporting (summarized in Table 2) do not cover the entire income distribution. They include figures only for taxpayers with incomes under $\$ 10,000$ and all persons who report business income regardless of their total income.

The total of $\$ 4.7$ billion of underreporting disclosed by the ACP appears at first to explain only a small portion of the $\$ 23$ billion gap; but on closer examination it explains quite a. good deal. It does not include the underreporting of taxpayers with incomes of $\$ 10,000$ or more who did not report business income. This could be derived directly from the ACP, and the IRS would perform a use-

\section{TABLE 2}

Amount of Underreporting of Adjusted Gross Income on Tax Returns Disclosed by the 1949 Audit Control Program

(millions of dollars)

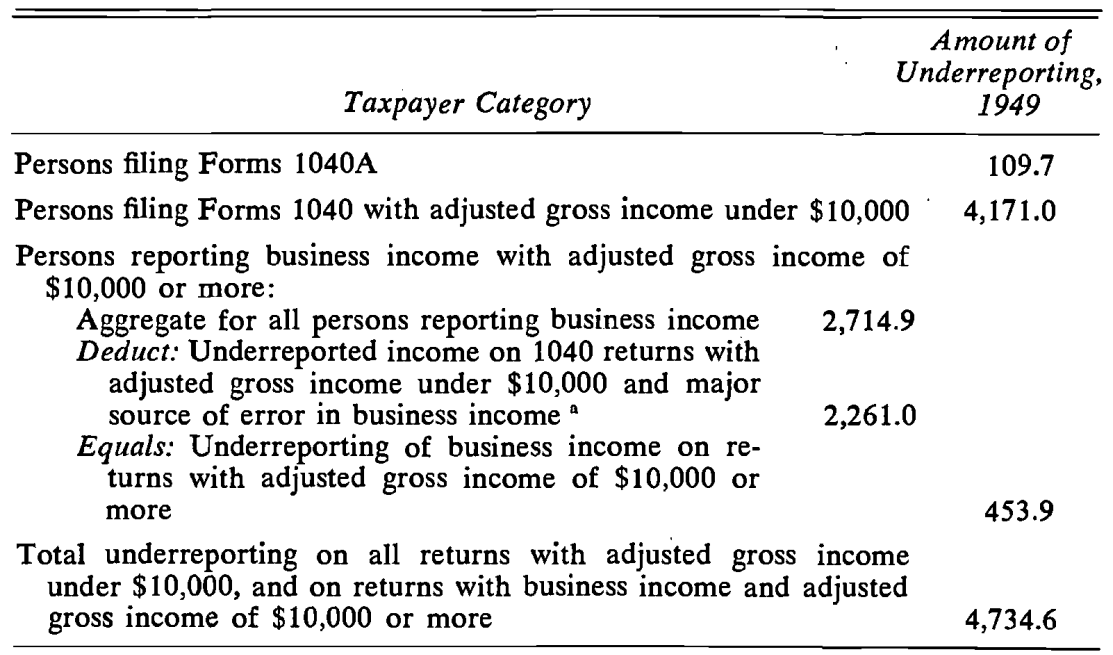

a Assumes that entire error in adjusted gross income is due to the major source of error.

Source: Marius Farioletti's paper in this volume, Tables 1, 2, 4, and 5. 


\section{A T CH I N G A N D Q UALITT STUDIES}

ful service if it made the tabulation available. In the absence of a direct figure, we can only hazard a guess. According to Farioletti's Table 2, persons filing Form 1040 with adjusted gross income under $\$ 10,000$ underreported their income by about 4.1 per cent. It is conceivable that the underreporting above $\$ 10,000$ would be of roughly the same proportion, but it is more likely that the proportion is lower because the returns of higher income taxpayers are subject to closer scrutiny by the revenue agents. If we assume that taxpayers with incomes above the $\$ 10,000$ level underreport their incomes by 2 per cent (half the percentage of those under $\$ 10,000$ ), then the total amount of underreporting not covered by Farioletti would be about $\$ 0.4$ billion. $^{2}$ Adding this to the $\$ 4.7$ billion shown in Table 2, we arrive at an estimated total of more than $\$ 5$ billion for the underreporting disclosed by the ACP at all income levels.

Aside from this $\$ 5$ billion, two other factors enter into the gap. First, there is a large difference between farm income included in the National Income Division's estimates of personal income and the tax return data corrected for Farioletti's audit results. The NID estimates total farm self-employment income as $\$ 10$ billion; while Farioletti estimates that, if every farm return were subject to a full field audit, we would obtain $\$ 5$ billion or about 23 per cent more than the amount reported by farmers. Second, Holland and Kahn have estimated that the wages and salaries received by persons not required to file returns probably amounted to about $\$ 1.5$ billion. Adding these two amounts to the estimated $\$ 5$ billion of underreporting by persons who file returns, we arrive at a total of $\$ 11.5$ billion, which is half of the $\$ 23$ billion gap between total adjusted gross income and adjusted gross income reported on tax returns. The remaining $\$ 11.5$ billion is the part of the gap which still remains unexplained (see Table 3 ).

The unexplained portion of the 1949 gap ( $\$ 11.5$ billion) amounts to about 5.5 per cent of total personal income ( $\$ 206.8$ billion). Does this mean that personal income is overestimated by that amount? The answer is obviously no. First, the sample used in the ACP was confined to persons who filed returns, and therefore it failed to pick up the incomes of persons who were required to file and did not. Also, as Farioletti pointed out, it is hardly likely that the field audits disclosed all of the unreported income on the returns examined.

My own view is that these factors are sufficient to account for

2 This figure was derived by multiplying the 2 per cent estimate by the total income other than business income or loss in the adjusted gross income classes of $\$ 10,000$ or more ( $\$ 20.8$ billion), as shown in Statistics of Income for 1949, Part 1, Table 2. 
TABLE 3

Reconciliation of Department of Commerce Estimate of Personal Income with Adjusted Gross Income Reported on Individual Tax Returns, 1949

(billions of dollars)

\begin{tabular}{lr}
\hline \multicolumn{1}{c}{ Item } & Amount \\
\hline 1. Personal income & 206.8 \\
2. Deduct: Conceptual differences & 23.1 \\
3. Equals: Total adjusted gross income & 183.7 \\
4. Deduct: & \\
a. Underreporting disclosed by 1949 ACP & 4.7 \\
b. Underreporting on incomes not covered by 1949 ACP & 0.4 \\
c. Farm entrepreneurial income not disclosed by 1949 ACP & 4.9 \\
d. Wages and salaries of persons not required to file tax returns & 1.6 \\
5. Deduct: Adjusted gross income reported on taxable and nontaxable & \\
$\quad$ individual income tax returns & 160.6 \\
6. Equals: Unexplained gap & 11.5 \\
\hline
\end{tabular}

Source

Line 1-Dept. of Commerce.

Line 2-Table 1.

Line 3-Table 1.

Line $4 a-$-Table 2.

Line $4 \mathrm{~b}$-Computed on the assumption that the percentage underreporting by persons with adjusted gross income of $\$ 10,000$ or more and incomes other than entrepreneurial incomes is half that of persons with adjusted gross income of less than $\$ 10,000$.

Line 4c-Difference between Dept. of Commerce estimate of farm entrepreneurial money income and amount of net profit from farming disclosed on audited tax returns (Marius Farioletti's paper in this volume, Table 2).

Line 4d-Estimate by Daniel M. Holland and C. Harry Kahn, "Comparison of Personal Income and Taxable Income," Federal Tax Policy for Economic Growth and Stability, Papers Submitted by Panelists appearing before the Subcommittee on Tax Policy, Joint Committee on the Economic Report, 1955, p. 335.

Line 5-Statistics of Income for 1949, Part 1, Table 2.

Line 6 -Lines 3 to 5 , inclusive.

the unexplained $\$ 11.5$ billion, and perhaps even more. But in any case, the official personal income estimates are probably not subject to a large margin of error and, assuming that the farm income estimate is correct, they may even be a bit low.

In conclusion, we are close to explaining the mysterious gap which has plagued us for so many years. More work on the incomes of persons not filing returns and another table by the IRS on the amount of underreporting by persons with incomes of $\$ 10,000$ or more would go a long way toward accounting for the part of the gap which remains unexplained.

\section{HYMAN B. KAITZ, DEPARTMENT OF LABOR}

The four papers on the matching studies cover hitherto largely unexplored territory and we can, perhaps, only begin to consider cer- 


\section{MATCHING AND QUALITY STUDIES}

tain general patterns which emerge from their findings. At first glance it seems reassuring to find such good agreement between surveys in the distribution of matched units by income level in view of the usual amount of dispersion in any table of consumer units cross-classified by the incomes reported to each of two surveys.

Such reassurance has been expressed about the influence on the results of response errors. For example, Miller and Paley say, "Fortunately, the variations in response elicited in repeated interviews appear to be random and do not introduce any systematic bias into the income distribution." Mandel, Wolkstein, and Delaney consider their analysis of differences in wages reported to the Bureau of Old-Age and Survivors Insurance and to the Post-Enumeration Survey "supports our previous findings, that is, the existence of a tendency for wage reporting errors to be reciprocally compensating. ...."

And yet, who will discount the intuitive judgment that response errors decrease the accuracy of the results of a single survey-the greater the relative response error, the greater the decrease in accuracy? If two surveys of the same people yield approximately the same income distributions, then what is the effect of the response errors? Some rough idea of the magnitude of these effects can be derived, for units whose incomes were positive in both surveys, from the data in Table 1 of the Sirken, Maynes, and Frechtling paper. I should like to discuss briefly and on a tentative basis some of the possible effects.

\section{SYSTEMATIC AND RANDOM ERRORS.}

First there is the notion of response error arising from the hypothetical repetition of the same survey many times on the same group of respondents, with the use of the same interviewers, interview situations, and questionnaires. For present purposes "true" income is defined as the average of all the incomes which would be reported by a unit to an indefinite number of repetitions of a survey. By this definition, true income may differ from the actual income received by the unit and create, in effect, a systematic response error for individual units. This type of response error is ignored here.

Random response error for a unit in a single survey is the difference between its income reported to that survey and the hypothetical average income of the unit for all repeated surveys. This kind of response error is attached to any survey or, in my opinion, to institutional records such as tax returns and OASI cards. If no survey is free of it, then an analysis of error based on a comparison of 
two surveys of the same people, for which there is no adequate benchmark, requires postulation of a response error model, formal or informal.

\section{TWO RESPONSE ERROR MODELS}

The systematic effects of response errors on an income distribution and its inequality will be examined under two simple response error models to test (indirectly) their correspondence with observation and to examine their properties and implications.

The simplest and most familiar model, expressed in terms appropriate to the present context, is that true incomes and errors (differences between true and reported incomes) are uncorrelated with each other. It should be assumed at the same time that error variance increases as true income rises since the usual (implicit) assumption of a uniform absolute error would mean that a person with a true income of $\$ 1,000$ is as likely to be in error in his reported income on a single survey by $\$ 400$ as a person with a true income of $\$ 100,000$ - a conclusion which is hard to accept. However, for some illustrative purposes, a uniform absolute error is tentatively assumed in this model.

A second and more reasonable model is a restatement of the first model in terms of the logarithms of true income and income error. It follows from this model that a unit with a true income of $\$ 1,000$ is as likely to report a figure in error by 10 per cent as one with an income of $\$ 100,000$. This model makes more sense than the first, and I shall discuss it in more detail.

Under the first model the variance of the true income distribution is less than that of the observed income distribution. The arithmetic mean income is the same for both. Consequently, the coefficient of variation-a good measure of income inequality-is affected; the inequality of the true income distribution must clearly be less than that of the observed distribution. Similarly, under the second model, the logarithmic variance (another measure of inequality) of the true distribution is less than that of the observed distribution. ${ }^{1}$

\footnotetext{
${ }^{1}$ For the first model, the coefficient of variation is reduced by 10 per cent; for the second model, the logarithmic variance is reduced by 17 per cent. The observed distribution used here is an arithmetic average by income levels of the two marginal distributions, SCF and CQC, of units matched with positive incomes. The estimates are based on computed correlation coefficients between matched incomes (model 1) and matched income logarithms (model 2).

Part of the effect of response errors for each of the models could have been estimated from the cross-tabulation of $\mathrm{SCF}$ income by $\mathrm{CQC}$ incomes of the matched units, if the tabulation bad been sufficiently detailed. Under the second model, for example, if each unit were classified by the geometric mean of its SCF and CQC
} 
M A T C H I N G A N D Q U ALIT Y S T U D I E S

While the decrease in inequality of the income distribution is clearly presented by the use of the logarithmic variance, it is always desirable to show, if possible, the effect of response errors on the Lorenz curve of the distribution. For this purpose it was necessary to estimate the true income distribution directly. ${ }^{2}$ The Lorenz curves of the true and observed income distributions are given in Chart 1.

\section{Chart 1}

\section{Hypothetical Survey and "True" Income Distributions}

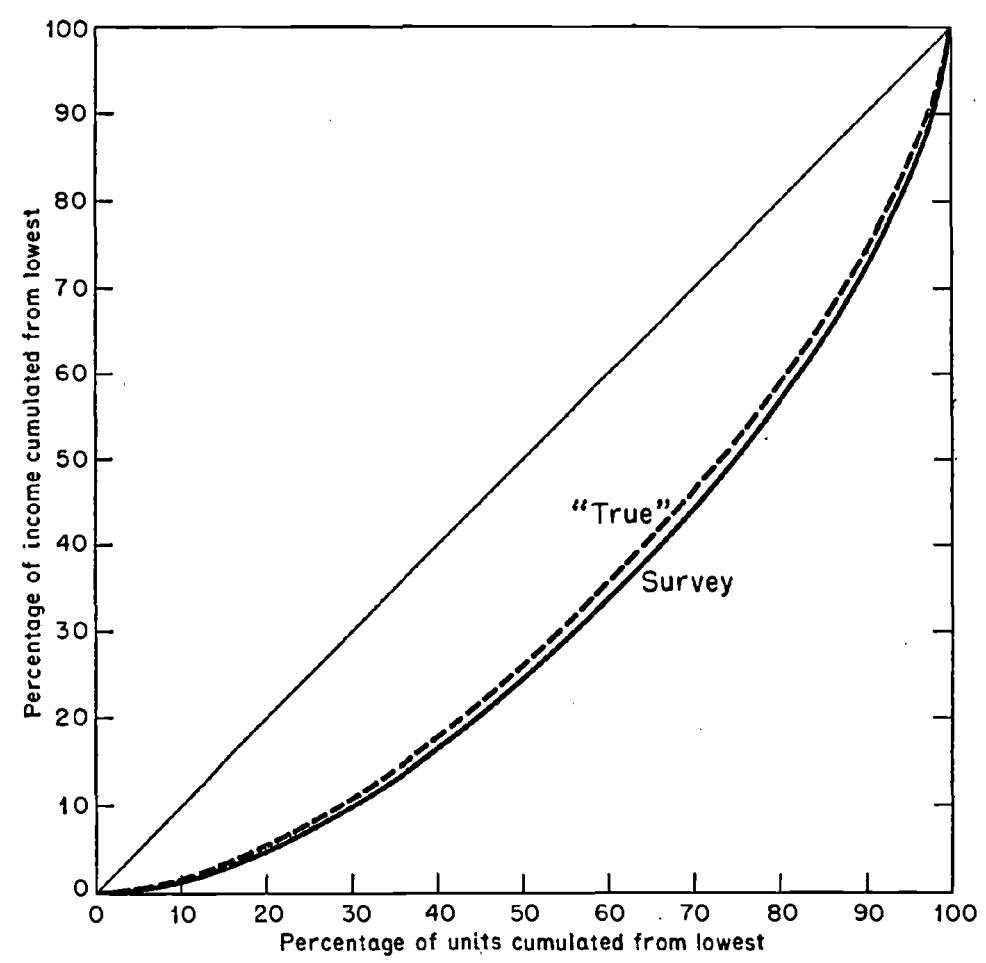

incomes, the resulting income distribution would be partially free of response error, and would in fact show a reduction in inequality (logarithmic variance) of half the total possible 17 per cent. The process of adding through the given crosstabulation to obtain this intermediate distribution with any reasonable accuracy was a rather formidable prospect.

${ }^{\mathrm{a}}$ The true distribution was obtained from the observed distribution by use of a linear transformation in the logarithms of income, with the constants of the transformation chosen so that the desired logarithmic mean and variance were obtained. Just as in the first model, the observed arithmetic mean income is also the true mean income, so in the second model the geometric mean income remains unchanged. 


\section{COMMON IMPLICATIONS OF THE MODELS}

Each of the two response error models have some unsatisfactory aspects, the first more than the second. However, even if more satisfactory models are developed, I believe some of their common implications will remain. It is reasonable to think that the inequality of an income distribution must be reduced if its random response errors are removed. Marginal propensities to consume, calculated from survey data on income and expenditures, should tend to increase with a reduction in response errors. This is seen most clearly under the second (logarithmic) model. To the extent that response errors result in the misclassification of units in some category-by family size, urban-rural, age of head, and so forthand these errors are not correlated with income, the comparisons of such categories in terms of income must necessarily be impaired.

Twice when working on the construction of income size distributions from survey and tax return data, I was impressed by a pattern among the incomes of family members. Once the distributions of survey incomes of subfamilies and of main families were almost independent of those of supplementary income recipients and family heads. ${ }^{3}$ Another time I found a marked correspondence between estimated distributions of combined family earnings (assuming independence of earnings in two-earner families) and observed survey distributions of family earnings. ${ }^{4}$ This lack of relationship among patterns of income of individual family members or family subunits must be due, at least in part, to the presence of random response errors in the basic survey data.

While response errors can hardly be eliminated entirely, a respectable body of theory can probably be developed for sharpening our tools of analysis. To this end, we must look for help to the people engaged in planning and conducting consumers surveys at the Michigan Center, the Census Bureau, the Bureau of Labor Statistics, and similar organizations.

\section{IRVING SCHWEIGER, UNIVERSITY OF CHICAGO}

These matching studies have been of considerable value. The contributing organizations and individuals should be congratulated

\footnotetext{
${ }^{3}$ Maurice Liebenberg and Hyman Kaitz, "An Income Size Distribution from Tax and Survey Data, 1944," in Volume Thirteen (1951) of Studies in Income and Wealth, pp. $426-429$.

"Income Distribution in the United States," Supplement to Survey of Current Business, 1953, pp. 50-51.
} 


\section{MATCHING AND QUALITY STUDIES}

for an important job well done. As a result of these studies some questions have been brought into much sharper focus.

The problem of "coverage" has been considerably clarified. Far more is now known than before on how many and which types of dwelling units, family members, and income recipients tend to be missed with various field procedures. Progress has been made in distinguishing and measuring differences in the quality of income information furnished by various family members.

These carefully matched studies have highlighted the magnitude of a rather neglected type of reporting error, variability in the reporting of individual incomes in field surveys. Only about half of all units placed themselves consistently in the same broad income bracket (intervals of $\$ 500$ or larger) in successive interviews a few weeks to a few months apart. For example, of the consumer units that reported incomes of $\$ 7,500$ to $\$ 9,999$ in the Census Quality Check just under half reported incomes within this same broad $\$ 2,500$ class interval in the Survey of Consumer Finances. Of the $\$ 7,500-\$ 9,999$ CQC group 10 per cent reported incomes of less than $\$ 5,000$ in the SCF, and 4 per cent reported less than $\$ 2,000$ of income. Such variability in reporting income information has implications for both reports on income levels and distributions and for any analysis related to income. If consumers reporting incomes of $\$ 4,000$ to $\$ 4,999$ in a field survey, for example, really have incomes ranging from $\$ 2,000$ to $\$ 10,000$ with only half actually receiving $\$ 4,000$ to $\$ 4,999$, then any analysis relating expenditures, savings, family characteristics, and so on to reported income level is almost certainly subject to serious error and distortions.

An illustration of these difficulties appears in the paper by Eleanor M. Snyder, who found that economic status, which is based on relatively long-term factors, was frequently not closely related to reports of current income level. Such a disparity can result from any of a number of socio-economic factors. However it is also bound to develop when persons with incomes of $\$ 2,000$ report incomes of $\$ 5,000$ and vice versa. Indeed, the validity of Miss Snyder's indexes of economic status may be verified by her finding of imperfect correlation between income level and economic status. While there are valid reasons why current income may differ from economic status, measurement of the phenomenon is confused by the variability of income reports and tends to be exaggerated by it.

The implications of these methodological findings appear even more serious for the field reporting of items other than income. There are few props to aid in recalling expenditures for food and clothing, increases and decreases in liquid funds, consumer debt, and so 
forth. Saving, for example, may be subject to wide margins of error because of its many forms, of irregularity in depositing or withdrawing, and lack of independent summations such as income withholding statements. Evidence from a small sample study in which reports on individual savings accounts were matched against bank records indicates that large errors in holdings are quite frequent both in their amounts and changes. ${ }^{1}$

Results of these matching studies of income and of savings accounts warn us that financial and possibly other data obtained in field studies using current methods are subject to serious error in level, distribution, slope of regression, and almost any other calculated statistic. Much variation offset for the entire population is not offset for subgroups. To discover that much of the difficulty in micro-economic analysis lies in variability in reporting is a valuable contribution.

The Sirken, Maynes, and Frechtling paper shows that, for income, variability was lowest (although still present) when first quality respondents were interviewed (heads of spending units in the SCF and individual income recipients in the CQC).

Authors of the analyses in this volume differ on the merits of many versus few questions for reducing random errors: Miller, Pritzker, and Sands believe that a few questions give about as good results as many in determining level; Sirken, Maynes, and Frechtling suggest that more detailed questions will reveal more supplementary and miscellaneous types of income. Data for entrepreneurial incomes are inconclusive; there is a suggestion that use of few questions may lead to greater variation in results. Mrs. Goldsmith's analysis indicates that shortening the farm questionnaire in the 1954 SCF led to a much greater deviation from estimates of aggregate farm income than in previous years.

A new approach to learning how to obtain valid and reliable information seems to be called for. In the long run it should be more productive and less expensive to invest funds in experimental designs that would furnish reliable evidence of the effect of variations in type, phrasing, and number of questions, and of sources of information (respondents, records). The Census Bureau's test of one versus two income questions was a beginning, but far more experimentation of this type is required. Increasing reliance on surveys for information used in formulating government and business policy

\footnotetext{
${ }^{1}$ See my paper, "Some Factors Affecting Saving of Different Groups," pp. 1-2, given at the Conference on Consumption and Economic Development of the Universities-National Bureau Committee for Economic Research in October 1955, mimeographed, for a brief description of the magnitude of these errors.
} 
MATCHING AND QUALITY STUDIES

underscores the importance of improving current inadequate survey methodology. These papers have made important contributions by showing how to overcome certain deficiencies in technique and by indicating the magnitudes of other hitherto unappreciated problems. 